\title{
Cultural perception of triatomine bugs and Chagas disease in Bolivia: a cross-sectional field study
}

Andrea Salm and Jürg Gertsch* ${ }^{*}$

\begin{abstract}
Background: Chagas disease remains a major public health risk in Bolivia, particularly among rural indigenous communities. Here we studied the cultural perception of the triatomine vectors and Chagas disease among selected rural and urban ethnic groups from different socio-economic and geographical milieus. We focused on the indigenous communities in the Bolivian Chaco where the disease is hyperendemic.
\end{abstract}

Methods: A cross-sectional study using field observations and structured interviews was carried out among 480 informants in five different regions of Bolivia. Additional semi-structured interviews were conducted. Statistical analyses were performed to determine the correlation of socio-economic variables and indigenous Chagas disease knowledge systems. A total of 170 domestic Triatoma infestans vectors were collected and infection with Trypanosoma cruzi was analyzed by real-time PCR.

Results: Triatomine bugs were associated with Chagas disease in $70.2 \%(n=480)$ of the responses (48.0\% Ayoreo, 87.5\% Chiquitano, 83.9\% Guaraní, 72.2\% Quechua, 46.1\% La Paz citizens and 67.7\% Santa Cruz citizens). Generally, indigenous informants have been educated on the association between triatomine bugs and Chagas disease by institutional anti-Chagas disease campaigns. While communities were largely aware of the vectors as a principal mode of disease transmission, rather unexpectedly, health campaigns had little influence on their prevention practices, apparently due to cultural constraints. Overall, $71.9 \%$ of the collected domestic vectors in the Chaco region were infected with T. cruzi, matching the high infection rates in the indigenous communities.

Conclusions: Among the Guaraní, Ayoreo and Quechua communities, the groups living in traditional houses have not integrated the scientific knowledge about Chagas disease transmission into their daily hygiene and continue to cohabit with T. infestans vectors hyperinfected with T. cruzi. An effective translation of Western disease concepts into traditional preventive measures is missing because asymptomatic infections are not generally perceived as threat by the communities. New participatory approaches involving existing ethnomedical knowledge systems could be a successful strategy in the control of T. cruzi infection.

Keywords: Chagas disease, Triatominae, Triatoma infestans, Knowledge systems, Perception, Vector, T. cruzi, Neglected tropical diseases, Bolivia 


\section{Background}

American trypanosomiasis, also known as Chagas disease (CD), is a chronic, systemic, parasitic life-long infection caused by the protozoan Trypanosoma cruzi [1]. About 6 to 7 million people are infected worldwide, mostly in Latin America, where the disease is endemic [2]. The parasite T. cruzi non-selectively infects mammals and birds and it is mainly transmitted to humans by hematophagous reduviid bugs of the subfamily Triatominae (Triatoma spp.) [1,3]. Transmission occurs subsequent to the insect blood meal when feces deposited by infected bugs come into contact with open wounds or mucous membranes $[1,2,4]$. Although mainly a vector-borne disease, $\mathrm{CD}$ also can be acquired by humans through uncontrolled blood transfusions and organ transplantation, congenitally, and through oral contamination [1].

$C D$ remains a major public health concern throughout much of Latin America. It is strongly associated with low socio-economic conditions $[5,6]$ and results in an economic burden [7]. Bolivia has the highest infection rates in the world and CD occurs in many geographical areas of the country [8-11]. Poor rural dwellings (traditional houses), where vectors progressively adapt and co-exist, are highly associated with parasite infection and CD [1215]. As a consequence, indigenous communities are more often affected by vector-mediated infection [16-18].

As there is neither a vaccine against infection nor a completely effective treatment for the chronic phase of the disease [19, 20], the Southern Cone Initiative has implemented control strategies that have been focused on the eradication of the vector through insecticide spraying campaigns (mainly pyrethroid insecticides) and screening of blood donors and pregnant women [21, 22]. In 1999, Bolivia launched the Chagas National Programme (Programa Nacional de Chagas) throughout endemic Departments of Bolivia with financial support from the Inter-American Development Bank (Banco Interamericano de Desarrollo, BID) and technical support from the Pan American Health Organization (PAHO). The programme consisted of an initial widespread, massive insecticide spraying campaign in the early 2000's [23, 24]. In 2006, the elimination of the disease was made a national priority by Bolivia's CD Law [25]. Besides vector control activities, diagnosis and free treatment were offered in all major cities. However, for the implementation of this initiative, the ethnic socio-cultural aspects of vector control were not taken into account. The knowledge and perception of CD and its vectors by the target population is of great importance for the success and sustainability of CD prevention. Consequently, the WHO has recognized the importance of incorporating social sciences into the study of neglected tropical diseases
[26]. Different studies in Latin America have reported on distinct knowledge and belief systems related to CD, showing central factors like the epidemiological severity of the disease, cultural background of the affected ethnic group and presence of vector control and health education activities [27-40]. Despite the CD endemicity in two-thirds of the country, little information is available about the knowledge related to triatomine vectors and CD in Bolivia, particularly in the Bolivian Chaco [41-43]. Infection prevention by vectors has been recognized to demand interdisciplinary, culturally sensitive approaches $[26,44,45]$. Given the fact that $C D$ is a chronic condition, which in only about $30 \%$ leads to a lethal cardio-digestive disease and only decades after the first infection [46, 47], the threat of infection is not immediately evident. Here we assessed to which extent selected indigenous ethnic groups in Bolivia associate CD with its triatomine vectors two decades after first vector control intervention.

\section{Methods}

\section{Study sites and population groups}

The survey was carried out between June 2014-August 2014 and November 2014-May 2015 in five different regions of Bolivia, in two major settlements (cities of La Paz and Santa Cruz) and in three different geographical rural areas (inter-Andean valleys, Chaco and Chiquitanía region). In 2017 and 2018 we revisited some locations. The communities and respective municipalities where the study was conducted are in the indicated rural zones (Fig. 1). The selection of the study sites was based on the reported incidence $\operatorname{CD}[9,15,48-51]$, cultural background, accessibility (prior informed consent) and varying degree of acculturation.

In the inter-Andean valleys, the population was native Quechua speaking and largely monolingual, while in the Chaco region the population was primarily of the Native American Guaraní ethnicity. Both are isolated regions due to restrictions in transportation and communication. In the Chaco, also Mennonite colonies are present. Individuals from the Mennonite religious community are of European descent, speak Plautdietsch and have little interaction with local people. Among this group, only unstructured interviews were conducted. In the Chiquitanía region, over $80 \%$ of the population belongs to the lowland ethnic group Chiquitano and are native Spanish speakers [52, 53]. Additionally, we included the Ayoreo ethnic group in our survey. Ayoreo people speak Ayoreode dialects of the Zamucoan family [54]. Traditionally nomadic hunter-gatherers, the majority of the communities have been sedentarized and acculturated by missionaries in the mid twentieth century, with the aim to integrate them into Bolivian society. During their process of acculturation, the Ayoreo communities have suffered 


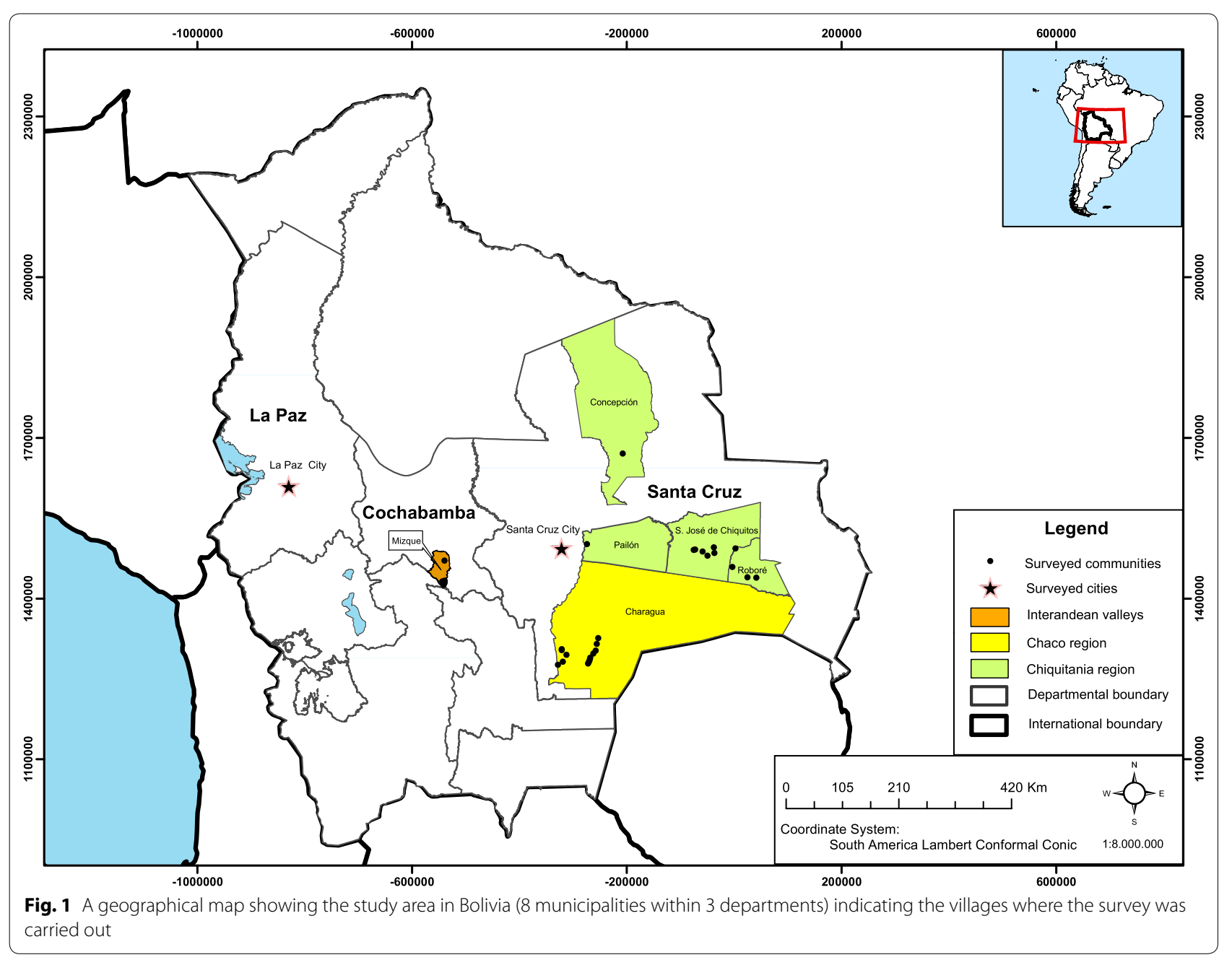

a traumatic change in their way of live and today are one of the most marginalized ethnic groups in Bolivia. Some striking problems are alcoholism, drug abuse and prostitution, particularly among young Ayoreo people [55]. The survey was carried out in rural Ayoreo communities in the Chiquitanía region and in urban Ayoreo settlements in the city of Santa Cruz de la Sierra. Moreover, the survey was conducted in the cities of Santa Cruz de la Sierra and La Paz. In both cities most of the population is of "mestizo" origin and native Spanish speakers. In the city of La Paz, a large proportion of inhabitants originated from Aymara rural communities.

CD transmission in all studied rural areas was endemic and varied from one region to another, with the highest infection rates reported from the Chaco region and inter-Andean valleys $[9,15,48-51]$. The later region has a history of high rates of human infection with T. cruzi [48] and is a reported location of sylvatic T. infestans [56-58] and of T. sordida [9]. The Gran Chaco has the highest prevalence of CD in the world [50]. Despite the presence of insecticide spraying campaigns in the last 15 years in this region, T. cruzi prevalence remains extraordinarily high, with close to universal infection among adults over 30 years-old [15, $49,59,60]$. In this region T. infestans, T. sordida and T. guasayana have been shown to infest houses [61, 62] and sylvatic populations of these tree species have been described [56, 57, 63-65]. In the Chiquitanía region, $T$. sordida and T. infestans have been reported to colonize dwellings [9]. In general, CD is associated with peasant families and rural dwelling infested by triatomine vectors. Nevertheless, migrations to the cities and increase of poverty in the urban areas have also transformed the disease into an increasingly urban health problem $[8$, $66,67]$. In fact, a study indicates a large prevalence of CD in Santa Cruz city, as an incidence of $23.6 \%$ of $T$. cruzi infection was detected in pregnant women [68]. Moreover, the presence of T. infestans and T. sordida has been reported in the metropolitan area of Santa Cruz city $[69,70]$. Owing to the altitude of La Paz city, 
this region is not an incidence area for triatomine bugs [51].

In all three rural areas, dwellings are predominantly constructed of wood and adobe walls, earthen floors and thatched roofs. Therefore, they constitute a suitable habitat for T. infestans (Fig. 2). Each household comprises one to four separate structures, usually of one or two rooms. Rooms are dark because of the wall materials and small windows. Animals, which are also hosts to $T$. infestans and other triatomine vectors (primarily T. sordida and T. guasayana in the Chaco) are raised in close proximity. The peridomestic area comprises several structures such as chicken coops, goat and sheep corrals. In all rural areas, the main economic activity is subsistence agriculture. CD related prevention activities have been carried out during the last decade as part of the Chagas National Programme, mostly as vector control intervention and to a lesser extent (in bigger settlements) serological surveys with pregnant women and school children $[21,24,51]$.
In the cities of La Paz and Santa Cruz, public and private hospitals, clinics, medical practitioners and pharmacies provide medical health care. The largest hospitals treat the full range of health issues. In all rural areas, bigger communities have primary health centers adapted to the very basic local needs, which offer children vaccination, assistance of pregnant women and ambulatory care (painkillers, antibiotics, anthelminthic drugs, rehydration salts, etc.). However, most of them are insufficiently equipped. Moreover, large distances and a lack of transport limit accessibility to health services in remote rural areas. In rural areas, respiratory infections, diarrheal diseases and dermatological disorders are the most common medical consultations in primary health centers $[51,71,72]$, which indicates the high prevalence of these illnesses. Moreover, after having been integrated to the Bolivian society, the Ayoreo have been exposed to a variety of diseases that were new to them [55]. Two emerging examples are diabetes and AIDS. The first is probably a consequence of the dramatic change of alimentary habits and the second is related to Ayoreo sex workers in the city of Santa Cruz.
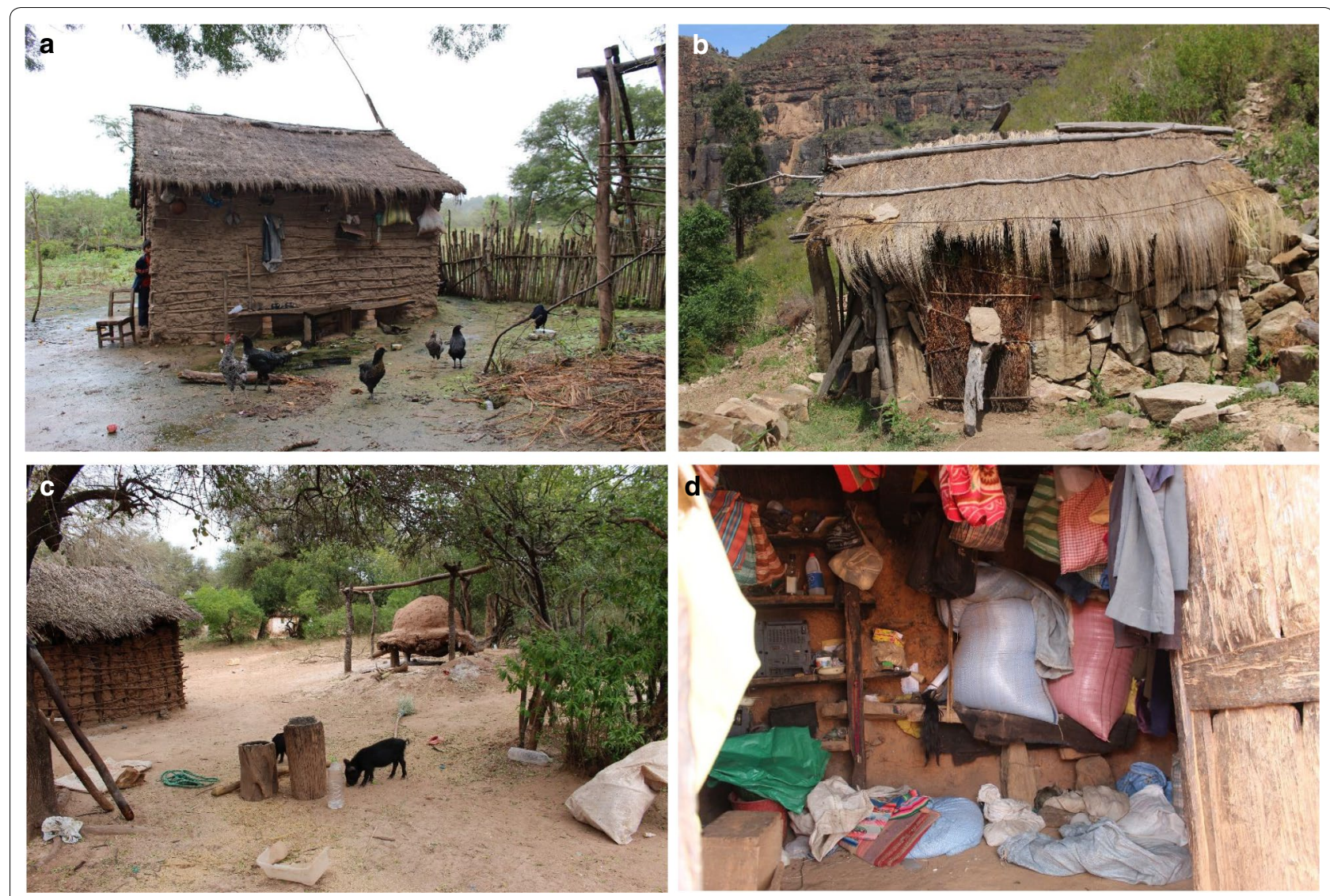

Fig. 2 Images of rural dwellings in the study sites. a Typical Guaraní house in the Chaco region. b Typical Quechua house in the interandean valleys. c Peridomicile structure close to a Guaraní house in the Isoso. d Interior of a Quechua dwelling 


\section{Study design and ethnographical data collection}

Ethnographic fieldwork by means of structured and semi-structured interviews provided a basis for the quantitative study. A structured questionnaire was designed to assess the cultural perception of CD and its Triatoma spp. vectors among the selected groups of the Bolivian population (Guaraní, Quechua, Ayoreo and Chiquitano indigenous peoples and residents of the cities $\mathrm{La} \mathrm{Paz}$ and Santa Cruz). It consisted of three major themes: (i) socio-demographic characteristics; (ii) knowledge and perception of triatomine vectors (local names, presence, perceived dangerousness); and (iii) awareness of $\mathrm{CD}$ (knowledge, direct experience or indirect through affected relatives, modes of transmission of the disease, sources of information). Questions related to knowledge of triatomine bugs were asked prior to the questions concerning CD in order to avoid bias. A total of 480 people between 10 and 80 years-old were interviewed. Informants were selected consecutively in order of appearance, each representing a different family and according to the prior informed consent, availability and willingness of the informants. A minimum of 50 interviews was carried out for each ethnic group or respectively city. For each visited community, a minimum of 10 representative interviews were conducted with local informants and corroborated by semi-structured interviews (see below). In some very small communities, the minimum number could not be achieved. In urban areas, interviews took place in public places, while in rural communities in the households during the visits. The interviews lasted from 10 to $30 \mathrm{~min}-$ utes. If possible, interviews were conducted in Spanish, else with the assistance of a local translator. Selected interviews were recorded by video. The informant's prior informed consent was obtained, and relevant socio-economic data were gathered. In rural areas, semi-structured interviews of approximately 60 to 90 minutes were based on general aspects of the informant's daily life in relation to and experience with $\mathrm{CD}$, focusing on the knowledge of insect vectors. Interviews related to the ecological knowledge about Triatoma spp. were recorded. Additionally, we conducted interviews with local health workers and fumigation technicians. The interviews and observations were registered in field notebooks, photographs or recorded as videos. Upon completion of the structured interviews (see above), the informants were educated about the role of triatomine bugs in $\mathrm{CD}$ transmission.

\section{Data analyses}

Structured interview data were collected in Microsoft Office Excel spreadsheets. Percentages were calculated for descriptive statistics. The obtained data were analyzed comparatively. Responses were compared among population groups, which were classified according to people's ethnicity. Hence, Ayoreo people living in urban settlements were included into the group Ayoreo. In a preliminary analysis, we found no significant differences in the responses of Ayoreo people living in urban or rural settlements. Further, analyses of the influence of sociodemographic and socio-economic factors on informants' responses were conducted within each population group. We calculated differences by Pearson's chi-square test of independence or Fisher's exact test. The connection of triatomine vectors and $C D$ was explored by means of logistic regression analysis (univariate and multivariate) from which odds ratios were computed. A $P$-value of 0.05 was considered as statistically significant. All statistical analyses were conducted using $\mathrm{R}$ software version $\mathrm{R}$ 3.1.1.

\section{Determination of infection of Triatoma vectors by T. cruzi}

A total of $170 \mathrm{~T}$. infestans bugs were collected during the fieldwork from six rural communities in the Chaco region and from two rural communities in the interAndean valleys. Insects were collected from domestic and peridomestic areas (by local residents), transported to the laboratory and stored at $-20{ }^{\circ} \mathrm{C}$ before analysis. Dead vectors were dissected with a razor blade for DNA extraction and 20-25 $\mathrm{mg}$ of tissue from each insect's abdomen were transferred in a micro-centrifuge tube with a forceps. In order to avoid cross-contamination, all tools were washed with bleach and rinsed with water after each dissection. DNA extraction followed using the DNeasy kit (Qiagen, Valencia, CA, USA) according to the protocol for animal tissues. The lysis step was conducted over night. DNA yield was determined using a NanoDrop 1000 spectrophotometer (Thermo Scientific, Waltham, MA, USA). Infection with T. cruzi was analyzed by realtime PCR. Each PCR reaction was performed in $10 \mu \mathrm{l}$ containing $5 \mu$ of Fast $\mathrm{SYBR}^{\circledR}$ Green Mastermix (Applied Biosystems, Foster City, CA, USA), $0.4 \mu \mathrm{M}$ T. cruzi specific primers TCZ1-F (5'-CGA GCT CTT GCC CAC ACG GGT GCT-3') and TCZ2 R (5'-CCT CCA AGC AGC GGA TAG TTC AGG-3'), which amplify 188 bp of a repetitive nuclear sequence [73], 30-50 ng DNA and molecular biology grade water. The PCR cycling program consisted of an initial denaturation at $95{ }^{\circ} \mathrm{C}$ for $20 \mathrm{~s}, 40$ cycles of $95{ }^{\circ} \mathrm{C}$ for $1 \mathrm{~s}$ and $60{ }^{\circ} \mathrm{C}$ for $20 \mathrm{~s}$. Amplification was followed by a melting program with an initial denaturation at $95{ }^{\circ} \mathrm{C}$ for $15 \mathrm{~s}$, cooling to $60{ }^{\circ} \mathrm{C}$ for $1 \mathrm{~min}$ and then a stepwise temperature increase of $2.63^{\circ} \mathrm{C} / \mathrm{s}$ from 60 to $95^{\circ} \mathrm{C}$. For each 96 -well reaction plate a standard curve was generated from 5 dilutions of positive control. Efficiencies of the amplification were calculated $\left(E=10^{(-1 /}\right.$ slope)). Negative controls consisted of a reaction with $T$. cruzi-specific primers without DNA. Each sample was evaluated in duplicate. 


\section{Results}

\section{General characteristics of informants}

Upon prior informed consent, we conducted structured oral interviews based on a questionnaire with 480 informants representing different gender and age groups. Table 1 summarizes the general socio-demographic characteristics of the overall study population.

\section{Knowledge, experience and perception of CD and its vectors}

The community knowledge, experience and perception of $C D$ and its vectors were assessed with a questionnaire, accompanied by pictures of two species of triatomine bugs ( $T$. infestans and T. sordida) in distinct nymphal stages for identification. In cases where the bug was identified, $T$. infestans was the species pointed most frequently. Only in few cases also T. sordida was recognized as a different species. A black and less dangerous vinchuca was mentioned in the Chaco, possibly referring to Panstrongylus megistus. Results of the interviews and differences among the studied population groups are summarized in Table 2.

\section{Naming triatomines: general and vernacular nomenclature} Vinchuca was the most commonly name used for triatomine bugs and generic for different Triatoma species. The term was used in all surveyed regions. Ethnic vernacular names were timbucu, used by Guaraní people, chanyupoay (T. infestans) and dipeche (T. sordida), used by Ayoreo and uluchi, used by Quechua. The last term was mostly referred to nymphal stages of the insect. The Mennonites living in the Chaco area refer to the bug as steinkwainz, referring to the Mennonite Low German (Plautdietsch) term for bugs or bluttier (blood animal).

\section{Triatomine knowledge and experience}

Overall, the vector was correctly identified in $79.8 \%$ $(n=480)$ of all surveyed subjects (Table 2). However, there were significant differences among the studied groups $\left(\chi^{2}=84.4, P<0.0001\right)$. Rural indigenous informants from all four studied ethnic groups correctly identified triatomine bugs in over $80 \%$ cases, while informants from the cities did this in 50.6\% (La Paz) and 66.1\% (Santa Cruz). The existence of vectors and the associated experience were examined by asking informants whether they had seen triatomine bugs. As expected, the studied ethnic groups and urban residents of the cities had very distinct direct experiences with the vector and their answers about having ever seen them significantly differed $\left(x^{2}=126.0, P<0.0001\right)$. Expectedly, indigenous people living in rural areas were more knowledgeable of triatomine bugs (vinchucas) and claimed to have encountered them more often than people living in the cities (see Table 2, Fig. 3). Informants in the rural areas had a detailed knowledge of T. infestans and its habits in general. In all rural regions, some informants mentioned a higher presence of the insect during hot and dry weather conditions, others referred to the blood-feeding behavior, while others mentioned a flying behavior of bugs "coming from the woods to the houses" and some mentioned the night activity of the bugs. In all rural areas, informants affirmed to have seen vinchucas inside the houses, by the corrals and in the woods. Many of the affected communities asserted that there was a decrease of triatomine bugs

Table 1 Socio-demographic characteristics of the individuals participating in the survey

\begin{tabular}{|c|c|c|c|c|c|c|}
\hline $\begin{array}{l}\text { Socio- } \\
\text { demographic } \\
\text { characteristics }\end{array}$ & $\begin{array}{l}\text { Ayoreo }(n=50) \\
n(\%)\end{array}$ & $\begin{array}{l}\text { Chiquitano }(n=120) \\
n(\%)\end{array}$ & $\begin{array}{l}\text { Guarani }(n=87) \\
n(\%)\end{array}$ & $\begin{array}{l}\text { Quechua }(n=72) \\
n(\%)\end{array}$ & $\begin{array}{l}\text { Citizens L.P. }(n=89) \\
n(\%)\end{array}$ & $\begin{array}{l}\text { Citizens S.C. }(n=62) \\
n(\%)\end{array}$ \\
\hline \multicolumn{7}{|l|}{ Sex } \\
\hline Male & $26(52.0)$ & $58(48.3)$ & $26(29.9)$ & 35 (48.6) & $43(48.3)$ & $33(53.2)$ \\
\hline Female & $24(48.0)$ & $62(51.7)$ & $61(70.1)$ & 37 (51.4) & $46(51.7)$ & $29(46.8)$ \\
\hline \multicolumn{7}{|l|}{ Age group } \\
\hline $10-20$ & $5(10.0)$ & $9(7.5)$ & $7(8.0)$ & 12 (16.7) & $13(14.6)$ & $11(17.7)$ \\
\hline $21-40$ & $18(36.0)$ & 45 (37.5) & $29(33.3)$ & 34 (47.2) & 45 (50.6) & $24(38.7)$ \\
\hline $41-60$ & $20(40.0)$ & $35(29.2)$ & $40(46.0)$ & 19 (26.4) & 21 (23.6) & $15(24.2)$ \\
\hline $61-80$ & 7 (14.0) & $31(25.8)$ & 11 (12.6) & $7(9.7)$ & $10(11.2)$ & $12(19.4)$ \\
\hline \multicolumn{7}{|c|}{ Educational level } \\
\hline None & $10(20.0)$ & $0(0)$ & $5(5.7)$ & $9(12.5)$ & $0(0)$ & $0(0)$ \\
\hline Primary & $39(78.0)$ & $62(51.7)$ & $74(85.1)$ & 53 (73.6) & $26(29.2)$ & $13(21.0)$ \\
\hline Secondary & $1(2.0)$ & $48(40)$ & $7(8.0)$ & $9(12.5)$ & $36(40.4)$ & $30(48.4)$ \\
\hline University & $0(0.0)$ & $10(8.3)$ & $1(1.1)$ & $1(1.4)$ & $27(30.3)$ & 19 (30.6) \\
\hline
\end{tabular}


Table 2 Knowledge, perception and awareness of Chagas disease and its triatomine vectors of participants according to their ethnicity

\begin{tabular}{|c|c|c|c|c|c|c|c|c|}
\hline Survey question & $\begin{array}{l}\text { Ayoreo } \\
n(\%)\end{array}$ & $\begin{array}{l}\text { Chiquitano } \\
n(\%)\end{array}$ & $\begin{array}{l}\text { Guarani } \\
n(\%)\end{array}$ & $\begin{array}{l}\text { Quechua } \\
n(\%)\end{array}$ & $\begin{array}{l}\text { La Paz } \\
n(\%)\end{array}$ & $\begin{array}{l}\text { Santa Cruz } \\
n(\%)\end{array}$ & $\begin{array}{l}\text { Total } \\
n(\%)\end{array}$ & $\begin{array}{l}P \text {-value } \\
X^{2} \text { test }\end{array}$ \\
\hline \multicolumn{8}{|c|}{ Identification of triatomine bugs } & $<0.0001$ \\
\hline Yes & $46(92.0)$ & $100(83.3)$ & $86(98.9)$ & $65(90.3)$ & $45(50.6)$ & $41(66.1)$ & $383(79.8)$ & \\
\hline No & $4(8.0)$ & $20(16.7)$ & $1(1.1)$ & $7(9.7)$ & $44(49.4)$ & $21(33.9)$ & $97(20.2)$ & \\
\hline \multicolumn{8}{|c|}{ Have seen triatomine bugs } & $<0.0001$ \\
\hline Yes & $46(92.0)$ & $98(81.7)$ & $87(100.0)$ & $61(84.7)$ & $31(34.8)$ & $39(62.9)$ & $362(75.4)$ & \\
\hline No & $4(8.0)$ & $22(18.3)$ & $0(0.0)$ & $11(15.3)$ & $58(65.2)$ & $23(37.1)$ & $118(24.6)$ & \\
\hline \multicolumn{8}{|c|}{ "Do you think this bug is dangerous?" } & 0.0003 \\
\hline Yes & $46(92.0)$ & $114(95.0)$ & $83(95.4)$ & $64(88.9)$ & $70(78.7)$ & $45(72.6)$ & $422(87.9)$ & \\
\hline No & $2(4.0)$ & $4(3.3)$ & $2(2.3)$ & $4(5.6)$ & $10(11.2)$ & $8(12.9)$ & $30(6.3)$ & \\
\hline Does not know & $2(4.0)$ & $2(1.7)$ & $2(2.3)$ & $4(5.6)$ & $9(10.1)$ & $9(14.5)$ & $28(5.8)$ & \\
\hline \multicolumn{8}{|c|}{ "Have you heard of Chagas disease?" } & $<0.0001$ \\
\hline Yes & $41(82.0)$ & $112(93.3)$ & $83(95.4)$ & $64(88.9)$ & $66(74.2)$ & $59(95.2)$ & $425(88.5)$ & \\
\hline No & $9(18.0)$ & $8(6.7)$ & $4(4.6)$ & $8(11.1)$ & $23(25.8)$ & $3(4.8)$ & $55(11.5)$ & \\
\hline \multicolumn{8}{|c|}{ "Do you have a family member who has Chagas disease?" } & $<0.0001$ \\
\hline Yes & $23(46.0)$ & $43(35.8)$ & $46(52.9)$ & $32(44.4)$ & $12(13.5)$ & $22(35.5)$ & $178(37.1)$ & \\
\hline No & $24(48.0)$ & $77(64.2)$ & $30(34.5)$ & $27(37.5)$ & $77(86.5)$ & $39(62.9)$ & $274(57.1)$ & \\
\hline Does not know & $3(6.0)$ & $0(0.0)$ & $11(12.6)$ & $13(18.1)$ & $0(0.0)$ & $1(1.6)$ & $28(5.8)$ & \\
\hline \multicolumn{8}{|c|}{ Association of triatomine bugs and Chagas disease } & $<0.0001$ \\
\hline Yes & $24(48.0)$ & $105(87.5)$ & $73(83.9)$ & $52(72.2)$ & $41(46.1)$ & $42(67.7)$ & $337(70.2)$ & \\
\hline No & $26(52.0)$ & $15(12.5)$ & $14(16.1)$ & $20(27.8)$ & $48(53.9)$ & $20(32.3)$ & $143(29.8)$ & \\
\hline
\end{tabular}
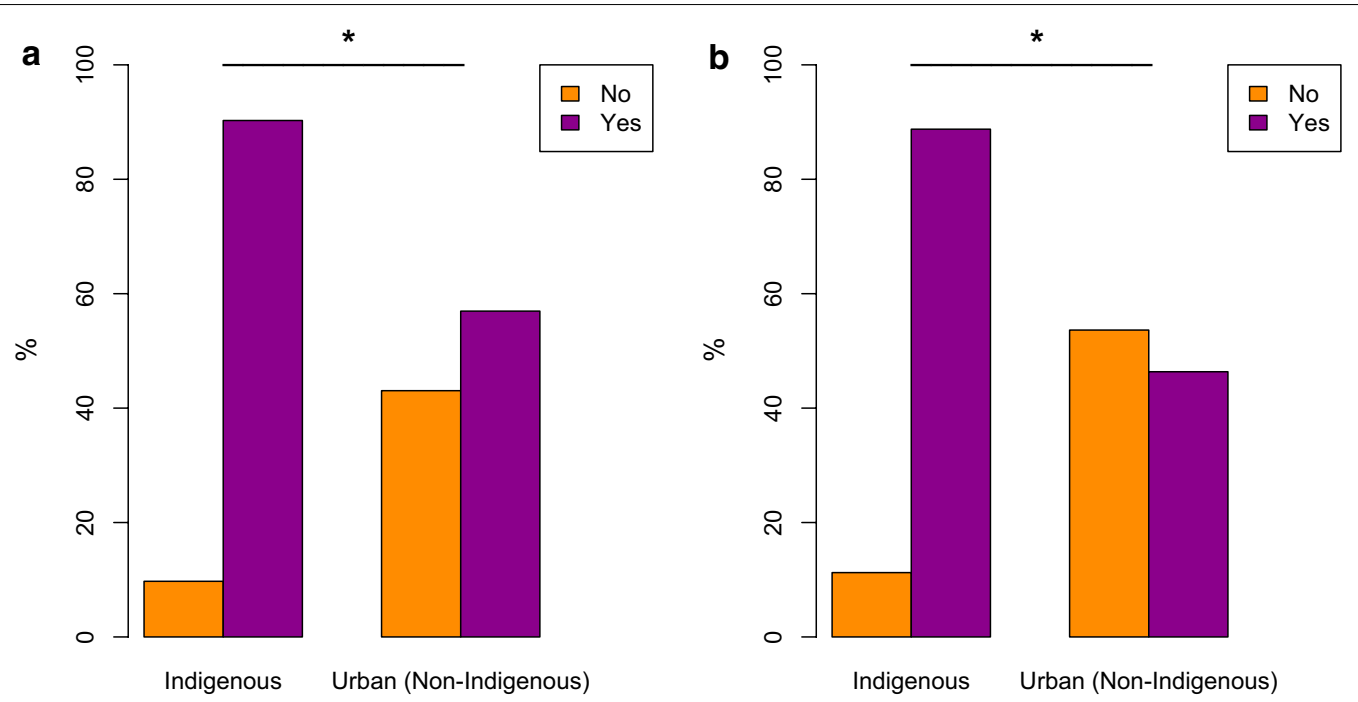

Fig. 3 Comparison of knowledge and experience with triatomine bugs between indigenous and urban (non-indigenous) informants. a Proportion of informants who correctly identified pictures of triatomine bugs $(n=480)$. $\mathbf{b}$ Proportion of informants claiming to have seen triatomine bugs $(n=480)$. *Significant association $(P<0.05)$

during the last decade and attributed this to the presence of vector control strategies (insecticide spraying). However, vectors were only temporarily eliminated from these communities. In fact, some communities, especially in the Isoso district (Chaco) lived in highly infested dwellings (see below). Generally, reports on number of vectors present in the community varied and could only be 
assessed by vector sample collection in the houses (see below).

\section{Perception of vinchucas}

In general, vinchuca bites were regarded as unpleasant. The vinchuca itself was considered dangerous by $87.9 \%$ $(P=0.0003)$ of all informants $(n=480)$ when this question was posed. Interestingly, some informants in the Chiquitanía and Chaco region distinguished between red and black vinchucas and claimed that only the former were dangerous. The black vinchucas might be Panstrongylus megistus while the red vincuchas were associated to $T$. infestans. In the village of Santiago de Chiquitos (Chiquitanía region) it was often stated that the red vinchucas coming from the Chaco region (which arrived together with immigrant workers from that region) are dangerous, while the black vinchucas from Santiago are not, since these attack wild animals but no human beings. Informants were asked to identify the reason/s why triatomine bugs are dangerous. Answers are presented in Table 3. CD was spontaneously mentioned by $47.3 \%(n=480)$ of the informants (24.0\% among Ayoreo, 68.3\% among Chiquitano, 58.6\% among Guaraní, $44.4 \%$ among Quechua, $25.8 \%$ among La Paz citizens, $43.5 \%$ among Santa Cruz citizens). In general, the relationship of vinchucas and a disease was largely identified, even if the disease was not explicitly named. The bite itself as the reason was the answer of $5.8 \%(n=480)$ of the interviewees (by $12.0 \%$ Ayoreo, 3.3\% Chiquitano, 8.0\% Guaraní, 4.2\% Quechua, 6.7\% La Paz citizens and 3.2\% Santa Cruz citizens). Some informants $(4.2 \%, n=480)$ referred to insects carrying a poison, probably due to the acute symptoms after the bite, while others $(4.4 \%, n=480)$ mentioned the bloodsucking behavior of the bug. Interestingly, among the Mennonites, vinchucas were generally not associated with CD but said to suck blood from domestic animals like chicken, which makes them sick.

Unexpectedly, the large proportion of positive answers about vinchucas being dangerous is contradictory to the observed behavior in the field. A natural cohabitation with vinchucas in rural Guaraní, Ayoreo and Quechua households and a lack of threat perception of these insects were commonly observed. Vinchucas did not awe rural informants and their ubiquitous presence did not seem to disturb them, in contrast to the knowledge about them being dangerous. Many inhabitants were familiar with the bugs and sighting them was a common event. For example, informants were not afraid to touch vinchucas with their bare hands. They claimed that vinchucas be sometimes disturbing, but they typically coexisted in the house. Consequently, vinchuca bites, although unpleasant, were considered normal and frequent. Among the Ayoreo, the vector disease association was significantly lower (Table 3). Moreover, a large proportion of indigenous informants, regardless of the ethnic group, mentioned that they heard that vinchucas have a disease or diseases. Some informants were skeptical and did not truly believe that the triatomine bugs were dangerous. As one male Ayoreo informant stated, "It bit me previously, but I didn't feel anything of the disease". On the contrary, in urban areas (La Paz and Santa Cruz) people clearly perceived vinchucas as dangerous and expressed their fear of this bug.

Table 3 Question survey: “Why is this bug dangerous?”

\begin{tabular}{|c|c|c|c|c|c|c|c|}
\hline & $\begin{array}{l}\text { Ayoreo } \\
\%(n=50)\end{array}$ & $\begin{array}{l}\text { Chiquitano } \\
\%(n=120)\end{array}$ & $\begin{array}{l}\text { Guarani } \\
\%(n=87)\end{array}$ & $\begin{array}{l}\text { Quechua } \\
\%(n=72)\end{array}$ & $\begin{array}{l}\text { La Paz } \\
\%(n=89)\end{array}$ & $\begin{array}{l}\text { Santa Cruz } \\
\%(n=62)\end{array}$ & $\begin{array}{l}\text { Total } \\
\%(n=480)\end{array}$ \\
\hline Chagas disease & 24.0 & 68.3 & 58.6 & 44.4 & 25.8 & 43.5 & 47.3 \\
\hline Chagas symptoms mentioned & 6.0 & 2.0 & 4.6 & 2.8 & 5.6 & 1.6 & 3.8 \\
\hline It has a disease/s & 22.0 & 7.5 & 13.8 & 8.3 & 7.9 & 6.5 & 10.2 \\
\hline It makes us feel sick & 4.0 & 0.8 & 2.3 & 8.3 & na & na & 2.3 \\
\hline Lethal disease & 4.0 & 2.5 & 1.1 & 5.6 & 3.4 & na & 2.7 \\
\hline Bites are a nuisance & 12.0 & 3.3 & 8.0 & 4.2 & 6.7 & 3.2 & 5.8 \\
\hline It sucks blood & 8.0 & 0.8 & 5.7 & 5.6 & 1.1 & 3.2 & 3.5 \\
\hline Poisonous & 4.0 & 3.3 & na & 5.6 & 5.6 & 9.7 & 4.4 \\
\hline Appearance & na & 1.7 & na & na & 11.2 & 3.2 & 2.9 \\
\hline Every bug is dangerous & na & 1.7 & na & na & 5.6 & na & 1.5 \\
\hline Other reason & 6.0 & 0.8 & 1.1 & na & 4.5 & 3.2 & 2.3 \\
\hline Does not know & 6.0 & 3.3 & 2.3 & 9.7 & 14.6 & 16.1 & 8.1 \\
\hline Not dangerous & 4.0 & 3.3 & 2.3 & 5.6 & 7.9 & 9.7 & 5.2 \\
\hline
\end{tabular}

Abbreviation: na, not applicable 


\section{Knowledge of $C D$}

The term CD was familiar to the majority of the informants, as $88.5 \%$ of the interviewees $(n=480)$ recognized it as a disease. In agreement with the previous questions, many informants indicated vinchuca bites as the main mode of transmission. Guaraní and Chiquitano people were in general well aware of $C D$ in their communities and recognized its different clinical manifestations. However, among Quechua and Ayoreo informants, $\mathrm{CD}$ and its transmission seemed not always to be clear concepts. Some interviewees claimed to have heard about the illness, although they were not sure about the underlying pathology and symptoms, and transmission mechanisms. Altogether, only 9 informants (1.9\%) explicitly stated that the vinchuca feces transmit the illness. Transmission through blood or congenitally was mentioned by a small proportion of the interviewees (1.3\% and $1.5 \%)$.

Overall, a high proportion of informants (37.1\%, $n=480$ ) claimed either to suffer personally from CD or to have family members or relatives who were affected by the illness (Table 2). Especially, the studied communities in the region Chaco were severely affected. 52.9\% of the interviewees had CD history in their families. As one male Guaraní (aged 45) stated, "here almost everybody has Chagas". The majority of the affected people in the Chaco and Chiquitanía region suffered from heart disease, while a large proportion of the affected Quechua population suffered from digestive or mixed alterations. Mostly, people diagnosed with CD learnt about their condition after tests conducted at pregnancy, blood donation and sometimes at serological surveys in schoolchildren or in workers, whose employers required such tests. In some communities some informants remembered having been tested, but stated that they never got the results. In more remote locations, informants were never tested. In some Guaraní and Quechua informants there was a suspicion based on the symptoms.

The informants gave a wide range of sources of information related to $C D$. In indigenous communities, health facilities and health promoters were the most prominent sources (principal transmitters). For example, a female Guaraní (aged 41) stated, "sometimes doctors tell us that there is Chagas in Isoso". Another female Guaraní (aged 30) remembered, "about two years ago they came here and taught us, but I have already forgotten". Quechua and Guaraní informants mentioned announcements about $\mathrm{CD}$ over the radio as an important source of information. Ayoreo people mentioned health education workshops organized by external institutions at community meetings as another sources of information. Other informants in rural areas acquired their knowledge from technicians from spraying campaigns.
Association between triatomine vectors and CD

The data from the structured interviews were analyzed to assess the perceptual association between vinchucas and $\mathrm{CD}$. Responses that mentioned the relationship of triatomine bugs with $\mathrm{CD}$ or a chronic condition without naming the disease scored as positive answers. Many informants had heard about the term CD and about its relation to vinchucas. If they did not know the health consequences and/or clinical manifestations of the disease, their answers scored negative (no association).

Overall, vinchucas have been positively associated with CD in $70.2 \%$ cases $(n=480)$. However, there were significant differences $\left(\chi^{2}=70.2, P<0.0001\right)$ among the population groups, as $48.0 \%$ Ayoreo, $87.5 \%$ Chiquitano, 83.9\% Guaraní, 72.2\% Quechua, 46.1\% La Paz citizens and $67.7 \%$ Santa Cruz citizens could connect vinchucas' bites with a chronic health condition. Further, binomial univariate and multivariate logistic regression analyzes were performed in order to determine which sociodemographic and socio-economic factors influence the association between vinchucas and $C D$ within each studied population group (Table 4). Among Guaraní and Quechua informants, gender, age group and educational status were not significant $(P>0.05)$. We detected significant gender differences in the univariate regression analysis among the Ayoreo, Chiquitano and La Paz groups $(P<0.05)$. Within these three groups, males associated vinchucas with CD more often than females. After univariate logistic regression analysis, age had a significant influence $(P<0.05)$ on the responses among the Chiquitano informants and residents of La Paz and Santa Cruz. Among the La Paz group, the association between $\mathrm{CD}$ and its vector linearly increased with the age of the informants. The educational background clearly had an influence only among informants living in the surveyed urban areas in the univariate analysis $(P<0.05)$. La Paz and Santa Cruz citizens associated vinchucas and CD more frequently with increasing educational level. In general, the responses among rural interviewees appeared to be more homogeneous in comparison to urban interviewees (Fig. 4). The results of the multivariate analysis indicated that the variables age and educational level remained significant $(P<0.05)$ among urban informants from La Paz and Santa Cruz (Table 4). The factor gender remained significant in the final regression model among the Ayoreo and Chiquitano informants as only $29.2 \%$ of Ayoreo female informants connected triatomine vectors with $\mathrm{CD}$.

\section{Infection of vectors with $T$. cruzi}

A total of 170 triatomine bugs were collected from community houses (Fig. 5) and analyzed for infection with $T$. cruzi. We found that $62.9 \%$ of collected bugs $(n=107)$ 
Table 4 Univariate (unadjusted OR) and multivariate (adjusted OR) logistic regression to identify socio-economic variables for awareness of triatomine bugs as vectors of Chagas disease

\begin{tabular}{|c|c|c|c|c|c|}
\hline \multirow[t]{2}{*}{ Demographic background } & \multirow{2}{*}{$\begin{array}{l}\% \text { who connected } \\
\text { Bugs with Chagas }\end{array}$} & \multicolumn{2}{|l|}{ Unadjusted } & \multicolumn{2}{|l|}{ Adjusted } \\
\hline & & OR & $95 \% \mathrm{Cl}$ & $\mathrm{OR}$ & $95 \% \mathrm{Cl}$ \\
\hline \multicolumn{6}{|l|}{ Ayoreo participants } \\
\hline \multicolumn{6}{|l|}{ Age } \\
\hline$\leq 40^{*}$ & 34.8 & Reference & & Reference & \\
\hline $41-60$ & 65.0 & 3.48 & $1.02-12.89$ & 3.84 & $1.01-16.58$ \\
\hline \multirow[t]{2}{*}{$61-80$} & 42.9 & 1.41 & $0.23-8.02$ & 1.50 & $0.15-14.82$ \\
\hline & & $P=0.14$ & & $P=0.15$ & \\
\hline \multicolumn{6}{|l|}{ Gender } \\
\hline Female & 29.2 & Reference & & Reference & \\
\hline \multirow[t]{2}{*}{ Male } & 65.4 & 4.59 & $1.44-16.00$ & 4.79 & $1.40-18.67$ \\
\hline & & $P=0.012$ & & $P=0.016$ & \\
\hline \multicolumn{6}{|l|}{ Education } \\
\hline No formal education & 40.0 & Reference & & Reference & \\
\hline \multirow[t]{2}{*}{ Basic or higher } & 50.0 & 1.50 & $0.37-6.64$ & 1.30 & $0.20-9.44$ \\
\hline & & $P=0.57$ & & $P=0.78$ & \\
\hline \multicolumn{6}{|l|}{ Guaraní participants } \\
\hline \multicolumn{6}{|l|}{ Age } \\
\hline $10-20$ & 85.7 & 1.12 & $0.16-22.56$ & 1.51 & $0.18-34.53$ \\
\hline $21-40$ & 82.8 & 0.89 & $0.27-3.24$ & 0.88 & $0.24-3.41$ \\
\hline \multirow[t]{2}{*}{$>40^{\mathrm{a}}$} & 84.3 & Reference & & Reference & \\
\hline & & $P=0.97$ & & $P=0.92$ & \\
\hline \multicolumn{6}{|l|}{ Gender } \\
\hline Female & 83.6 & Reference & & Reference & \\
\hline \multirow[t]{2}{*}{ Male } & 84.6 & 1.08 & $0.32-4.27$ & 1.07 & $0.28-4.68$ \\
\hline & & $P=0.91$ & & $P=0.92$ & \\
\hline \multicolumn{6}{|l|}{ Education } \\
\hline No formal education & 80.0 & Reference & & Reference & \\
\hline Basic & 85.1 & 1.43 & $0.07-10.88$ & 1.39 & $0.07-10.61$ \\
\hline \multirow[t]{2}{*}{ Intermediate and higher ${ }^{a}$} & 75.0 & 0.75 & $0.03-10.78$ & 0.61 & $0.02-10.13$ \\
\hline & & $P=0.74$ & & $P=0.68$ & \\
\hline \multicolumn{6}{|l|}{ Chiquitano participants } \\
\hline \multicolumn{6}{|l|}{ Age } \\
\hline $10-20$ & 44.4 & 0.03 & $0.00-0.22$ & 0.02 & $0.00-0.16$ \\
\hline $21-40$ & 88.9 & 0.27 & $0.01-1.77$ & 0.22 & $0.01-1.67$ \\
\hline $41-60$ & 88.6 & 0.26 & $0.01-1.87$ & 0.30 & $0.01-2.31$ \\
\hline \multirow[t]{2}{*}{$61-80$} & 96.8 & Reference & & Reference & \\
\hline & & $P=0.0071$ & & $P=0.1$ & \\
\hline \multicolumn{6}{|l|}{ Gender } \\
\hline Female & 80.6 & Reference & & Reference & \\
\hline \multirow[t]{2}{*}{ Male } & 94.8 & 4.40 & $1.31-20.13$ & 5.05 & $1.25-29.97$ \\
\hline & & $P=0.028$ & & $P=0.03954$ & \\
\hline Education & & & & & \\
\hline Basic & 83.9 & Reference & & Reference & \\
\hline Intermediate and higher ${ }^{a}$ & 91.4 & 2.04 & $0.68-6.92$ & 3.64 & $0.96-16.50$ \\
\hline & & $P=0.22$ & & $P=0.069$ & \\
\hline
\end{tabular}


Table 4 (continued)

\begin{tabular}{|c|c|c|c|c|c|}
\hline \multirow[t]{2}{*}{ Demographic background } & \multirow{2}{*}{$\begin{array}{l}\% \text { who connected } \\
\text { Bugs with Chagas }\end{array}$} & \multicolumn{2}{|l|}{ Unadjusted } & \multicolumn{2}{|l|}{ Adjusted } \\
\hline & & OR & $95 \% \mathrm{Cl}$ & OR & $95 \% \mathrm{Cl}$ \\
\hline \multicolumn{6}{|l|}{ Quechua participants } \\
\hline \multicolumn{6}{|l|}{ Age } \\
\hline $10-20$ & 50.0 & Reference & & Reference & \\
\hline $21-40$ & 70.6 & 2.4 & $0.62-9.55$ & 2.76 & $0.65-12.27$ \\
\hline $41-60$ & 89.5 & 8.5 & $1.51-70.24$ & 10.64 & $1.73-95.18$ \\
\hline \multirow[t]{2}{*}{$61-80$} & 71.4 & 2.5 & $0.37-22.74$ & 3.07 & $0.41-30.58$ \\
\hline & & $P=0.16$ & & $P=0.13$ & \\
\hline \multicolumn{6}{|l|}{ Gender } \\
\hline Female & 64.9 & Reference & & Reference & \\
\hline \multirow[t]{2}{*}{ Male } & 80.0 & 2.17 & $0.76-6.60$ & 1.82 & $0.54-6.36$ \\
\hline & & $P=0.16$ & & $P=0.33$ & \\
\hline \multicolumn{6}{|l|}{ Education } \\
\hline No formal education & 66.7 & Reference & & Reference & \\
\hline Basic & 69.8 & 1.16 & $0.22-4.98$ & 1.19 & $0.20-6.41$ \\
\hline \multirow[t]{2}{*}{ Intermediate or higher } & 90.0 & 4.5 & $0.45-103.84$ & 5.69 & $0.46-151.45$ \\
\hline & & $P=0.44$ & & $P=0.37$ & \\
\hline \multicolumn{6}{|l|}{ La Paz participants } \\
\hline \multicolumn{6}{|l|}{ Age } \\
\hline $10-20$ & 15.4 & 0.05 & $0.00-0.32$ & 0.02 & $0.00-0.22$ \\
\hline $21-40$ & 40.0 & 0.17 & $0.02-0.76$ & 0.14 & $0.01-1.00$ \\
\hline $41-60$ & 61.9 & 0.41 & $0.05-2.15$ & 1.65 & $0.14-19.65$ \\
\hline \multirow[t]{2}{*}{$61-80$} & 80.0 & Reference & & Reference & \\
\hline & & $P=0.014$ & & $P=0.0043$ & \\
\hline \multicolumn{6}{|l|}{ Gender } \\
\hline Female & 34.8 & Reference & & Reference & \\
\hline \multirow[t]{2}{*}{ Male } & 58.1 & 2.60 & $1.12-6.25$ & 2.51 & $0.80-8.45$ \\
\hline & & $P=0.029$ & & $P=0.12$ & \\
\hline \multicolumn{6}{|l|}{ Education } \\
\hline Basic & 19.2 & 0.10 & $0.03-0.34$ & 0.05 & $0.01-0.25$ \\
\hline Intermediate & 47.2 & 0.38 & $0.13-1.06$ & 1.62 & $0.41-6.92$ \\
\hline \multirow[t]{2}{*}{ Advanced } & 70.4 & Reference & & Reference & \\
\hline & & $P=0.002$ & & $P=0.0014$ & \\
\hline \multicolumn{6}{|l|}{ Santa Cruz participants } \\
\hline \multicolumn{6}{|l|}{ Age } \\
\hline $10-20$ & 63.6 & 0.22 & $0.04-1.21$ & 0.14 & $0.01-1.03$ \\
\hline $21-40$ & 45.8 & 0.11 & $0.02-0.40$ & 0.06 & $0.01-0.30$ \\
\hline \multirow[t]{2}{*}{$>40^{\mathrm{a}}$} & 88.9 & Reference & & Reference & \\
\hline & & $P=0.0096$ & & $P=0.009$ & \\
\hline \multicolumn{6}{|l|}{ Gender } \\
\hline Female & 62.1 & Reference & & Reference & \\
\hline Male & 72.7 & 1.63 & $0.56-4.86$ & 0.88 & $0.23-3.25$ \\
\hline & & $P=0.372$ & & $P=0.85$ & \\
\hline Education & & & & & \\
\hline Basic & 38.5 & 0.17 & $0.03-0.75$ & 0.09 & $0.01-0.63$ \\
\hline Intermediate & 73.3 & 0.73 & $0.17-2.79$ & 0.88 & $0.16-4.70$ \\
\hline Advanced & 78.9 & Reference & & Reference & \\
\hline & & $P=0.05$ & & $P=0.035$ & \\
\hline
\end{tabular}

a Levels grouped together because of small sample size 

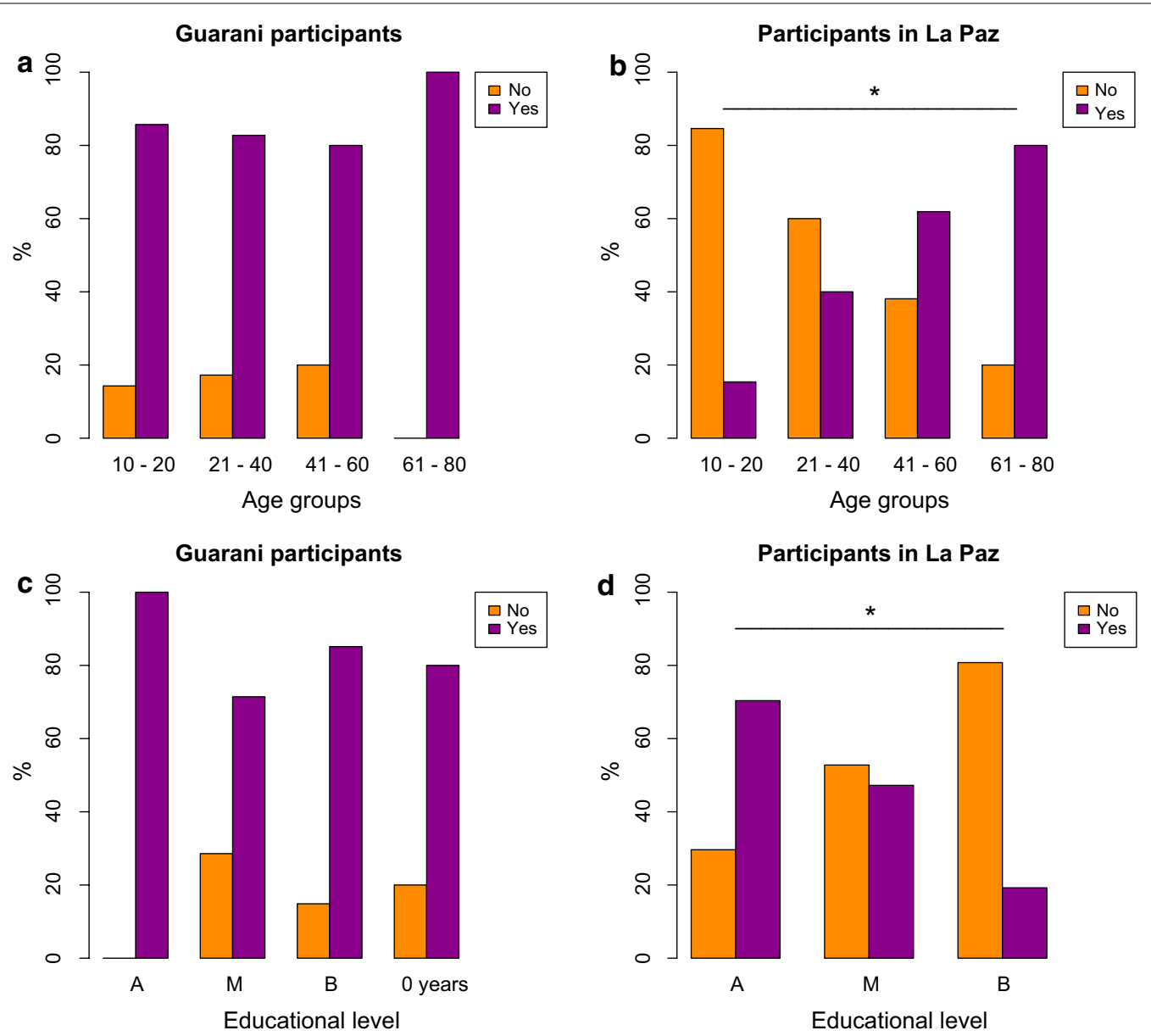

Fig. 4 Influence of age and educational level on Guaraní and La Paz informants' association of triatomine bugs and Chagas disease (CD). a Age and c educational level had no influence among Guaraní informants $(n=87)$ while both variables had an influence among informants in La Paz $(n=89)$, b and $\mathbf{d}$. *Significant association $(P<0.05)$
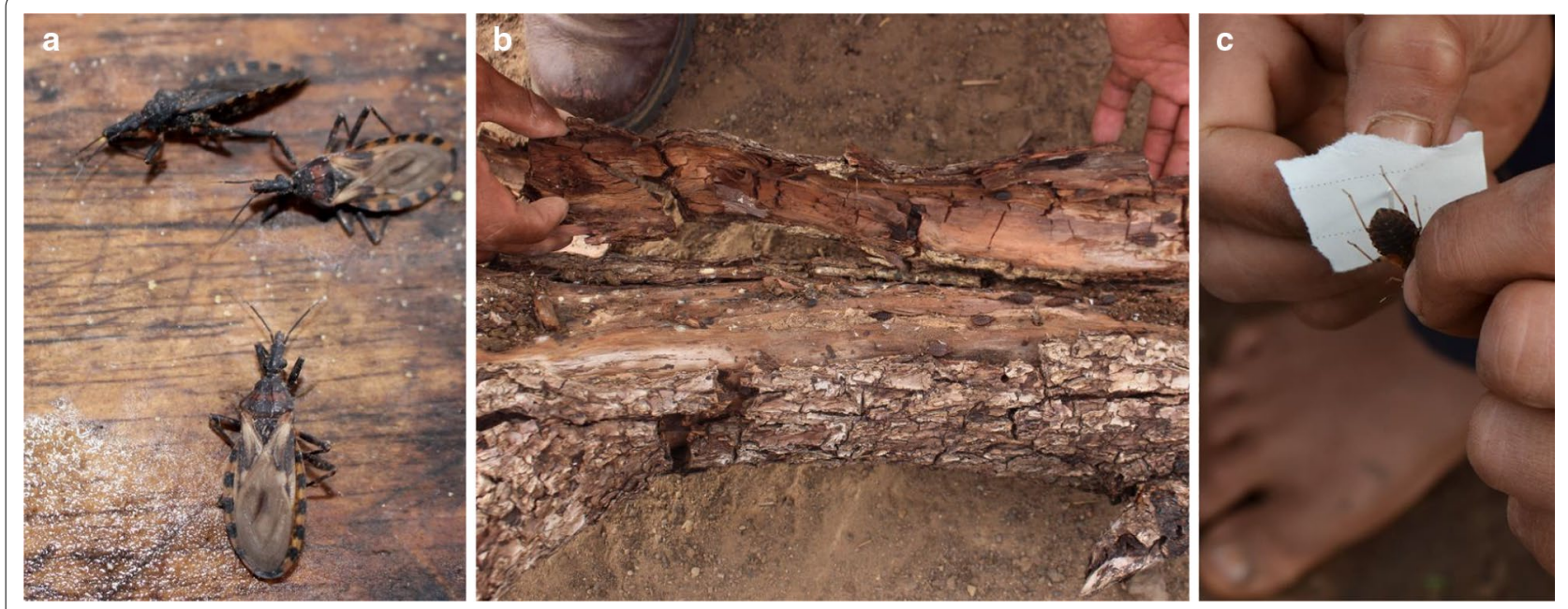

Fig. 5 Images of triatomine vectors. a T. infestans collected in a Guaraní dwelling in the Chaco. b Living nymph stage T. sordidas found inside tree trunk which was part of a structure of a sheep corral in the peridomestic area (Mizque municipaty). c T. infestans collected in a Guaraní house for subsequent real-time PCR analysis 
were infected with T. cruzi, and that $100 \%$ of the collection sites $(n=8)$ yielded $>1$ infected specimens. Geographical origin and infection rates are summarized in Fig. 6 . The percentage of infected insects per locality was variable (median 63.6\%, range 6.7-80.8\%). The variability is likely to the small sample size in some localities. Most of the collected insects were from Isoso district, where we found T. cruzi infection rates of $69.3 \pm 11.5 \%(n=118$ insects). In the Charagua district, $66.0 \pm 20.1 \%(n=28$ insects) of the collected triatomine vectors were infected. The real-time PCR analysis showed a lower T. cruzi infection of the insects collected in the communities located in the interandean valleys $(8.3 \%, n=24$ insects) in comparison with the two former districts located in the Chaco region.

\section{Discussion}

The data from this field study suggest that the majority of the interviewed informants had heard about CD and had knowledge about its vectors. Vinchucas (T. infestans) were associated with CD in $70.2 \%$ cases $(n=480)$. Our data show that the majority of the affected indigenous Chiquitano $(87.5 \%, n=120)$, Guaraní $(83.9 \%, n=87)$ and Quechua $(72.2 \%, n=72)$ population recognized the causal relationship between the insect's bites and CD, thus more frequently than the informants who lived in the cities Santa Cruz $(67.7 \%, n=62)$ and La Paz $(46,1 \%$, $n=89$ ). This is explained by the fact that in the La Paz region vectors are lacking. Intriguingly, in comparison to other ethnic groups, a significantly lower percentage (48.0\%) of Ayoreo informants associated triatomine bugs

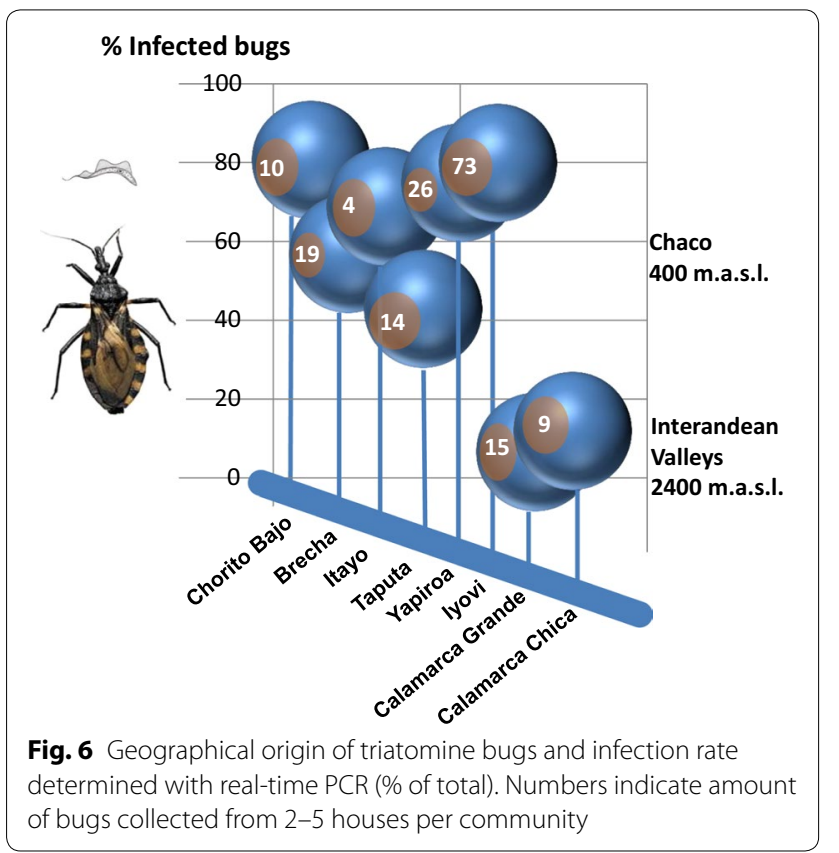

with CD, despite their overall good knowledge of Triatoma ecology. Multivariate logistic regression analyses indicate that age and educational level were significantly correlated $(P<0.05)$ with a better knowledge on the association between triatomine bugs and CD among urban informants, while there were unexpected gender differences $(P<0.05)$ among Ayoreo and Chiquitano informants concerning this knowledge. In the cities of $\mathrm{La} \mathrm{Paz}$ and Santa Cruz, the knowledge about triatomine vectors and $C D$ was mostly acquired through formal education and it linearly increased with age and educational level. In contrast, the responses of rural indigenous informants were mostly homogeneous (Fig. 3). Our data show that informants in rural areas know about triatomine bugs and $C D$ at an early age because age had no influence $(P>0.05)$ on the association between the two. This finding is not surprising as in indigenous societies adult-level knowledge is acquired at the age of 12 to 14 and there is generally a high consensus within a given community $[74,75]$. However, gender played a role among Ayoreo and Chiquitano informants. This is probably because males in these communities had higher literacy, or a better understanding of Spanish, especially in the case of Ayoreo informants. Unfortunately, Ayoreo women still lack education about CD and only $29.2 \%$ associated triatomine bugs with infection. This reveals that health education for both genders is necessary. Moreover, some Ayoreo informants reported that fumigation and health education campaigns did never take place in their villages. Clearly, in the Ayoreo ethnomedical system, disease concepts and etiologies strongly differ from Western biomedical concepts [76]. In the past, prolonged illness was generally considered of supernatural origin. The concept of curing diseases was embedded in ritual forms, shamanism and performative practices that constituted an Ayoreo "tradition" which has nowadays been entirely abandoned [77]. People no longer tell adode myths nor do they heal one another by sucking out or blowing away sickness with sarode and ujñarone curing chants, nor do they smoke sidi tobacco and canirojnai roots to enter into shamanic trances for spiritual healing [77]. After having been sedentarized in the second half of the twentieth century, the Ayoreo got exposed to new diseases like respiratory infections, diabetes and more recently also AIDS. There is the believe, especially among the older Ayoreo, that diseases come from the cojñone (non Ayoreo people) who are able to transmit them intentionally. For instance, we recorded an association between diabetes and being a community or political leader. Some Ayoreo say that diabetes in political leaders is caused by witchcraft from jealous people or that it is a punishment because of lying. Ethnomedical concepts have been largely unintelligible to anthropologists because 
of restricting Ayoreo acculturation to an impoverished notion of "tradition" which now represents both, a lack of shamanistic practice due to Christianization and a lack of knowledge about Western medicine.

All indigenous communities show a relatively good biological and ecological knowledge of the triatomine vectors $T$. infestans and T. sordida (e.g. reproduction, occurrence and general nocturnal blood sucking behavior), which is consistent with previous findings [32, 37, $41,43]$. However, the overall higher percentage regarding the association of vinchucas and CD significantly differed from previously conducted studies in similar endemic areas of Bolivia (Quechua [41] and Guaraní communities [43]), where there was limited knowledge of CD. This discrepancy may be attributed to the efforts of the national anti-CD campaigns in the surveyed rural areas. Indeed, a recent study within the Valleys and Chaco region identified that people recognized that $\mathrm{CD}$ is transmitted by Triatoma infestans to a similar extent as in our findings [42]. In another recent study in a rural, non-indigenous area of Santa Cruz Department all informants understood CD was transmitted by vinchucas and the majority recognized the symptoms of the disease [78]. However, our study is the first to provide information about the knowledge and perception concerning CD among Chiquitano and Ayoreo in Bolivia. In accordance to previous findings in endemic regions, the affected rural families have developed over time an attitude of naturalization of the problem and acceptance of triatomine bugs as they basically coexist with them [27, 29, 33, 37, 41, 42, 79]. However, contrary to other studies $[39,45]$, none of our informants mentioned having experienced discrimination or stigmatization because of having CD.

We found that in rural areas informants received health education about $\mathrm{CD}$ from non-indigenous institutions (mainly from municipal vector control personnel or health care workers). However, external transmitters had little impact on the perception regarding the threat of infection by vincuchas. The message of the anti-CD campaigns is therefore not convincing enough and does not transmit the nature of the risk to local communities. Knowledge and awareness of CD did not efficiently translate into changes in practice among the indigenous communities. No personal protection measures were implemented in the households visited. Preventive practices, such as restoration, amelioration and rigorous cleaning of the houses were rarely observed in the surveyed rural indigenous communities. Surprisingly, the informants did not report active searching for insects inside the dwellings or at the corrals. Moreover, a lack of hygiene and the presence of animal farming in close proximity were noticed in many indigenous communities. Domestic animals slept in the same room as family members, despite of people's awareness that vinchucas attack these animals as well. Such practices are causative for transmission of the infection as reported previously [80-82]. Occasional spraying with household insecticides was the only control action undertaken by some Chiquitano informants. Most of the affected population relies on the yearly national governmental insecticide campaigns. The Bolivian national Chagas campaign puts emphasis on organized vector control but not on personal protection measures. To date, no participatory approaches have been integrated in the surveyed communities.

The absence of actions against vector infestation of the houses could be explained by the CD pathophysiology. $\mathrm{CD}$ is a chronic condition that remains largely silent and manifests itself in about $30 \%$ of infected people, i.e. most patients will remain asymptomatic lifelong. In addition, there is a relatively low probability of being infected even when being continuously bitten [83]. These aspects are important when trying to understand people's behavior. The chance of getting a disease at some hypothetical future date does not seem to be a real problem. Something similar happens in Western countries where young adults still start smoking despite of being aware that smoking is associated with lung cancer [84]. Probably, the most disadvantaged sectors are the least likely to respond to health messages, as they are already under considerable strain coping with the exigencies of everyday life. Moreover, there is a divide between communities and health centers mainly because communication barriers exist in terms of language and lack of cultural understanding. The relationship between health personnel and indigenous people is sometimes plagued by mistrust [33]. Among doctors there is the tendency to perceive rural, indigenous peasants as inferior and often the prescription of medicines goes without explaining the diagnosis [33, 79, 85, 86]. For instance, we encountered Quechua and Ayoreo informants who were diagnosed with CD but did not know anything about this illness as nobody explained them what it meant "to be positive". In few extreme cases, Quechua and Ayoreo informants reported that they were tested but never obtained the result.

Despite the efforts to control the disease, it is still highly prevalent in some of the surveyed communities in the Chaco. Our PCR analysis reveals T. cruzi hyperinfection (infection rates of over 70\%) in domestic triatomine bugs. The difference between infected triatomine bugs in the interandean valleys and the Chaco (Fig. 6) may be because in the former, houses are temporarily abandoned (according to the agricultural cycle of the seasons) and the villages are less densely populated. Overall, the infestation of houses in this region was lower (a lower number of bugs was collected). Vector control was reported to be effective in a similar region in the inter-Andean 
valleys, where infestation of about $3 \%$ of dwellings was detected [87]. In both geographical regions, previous studies reported varying infection rates in $T$. infestans $[16,56,62,63]$, which ranged between $5-70 \%$, depending on the localities and habitat of the vectors (domestic or sylvatic). Clearly, the high T. cruzi prevalence in domestic triatomine vectors in the Chaco is contradictory to people's perception of vinchucas. Triatomine bugs were not attributed any particular (e.g. religious, ecological, ethnomedical) characteristics and no negative traditional cultural believes regarding these bugs could be recorded. Thus, it is likely that the millennial co-existence of parasite and host in this area did not induce a selection pressure to justify actions against the vectors. Indeed, the mortality of children due to T. cruzi infections among these communities is relatively low and many children are born from mothers already infected [88] and live long enough to get married and have children.

There is an urgent need to improve the efficacy of health education interventions. Our findings have identified some areas where campaigns or interventions could be targeted to enhance community health behavior. Educators should be better qualified. If possible, they should speak local languages and have training about ways to increase cultural sensitivity within their practices. Furthermore, innovative methods of educating residents of the local communities should be applied. Current health education models have the simple goal to impart knowledge through organized verbal instruction. However, learning always takes place in a specific socio-cultural setting. Learning in traditional rural societies is informal and experimental, taking place in an unstructured environment. Knowledge is acquired through hands-on experience and direct observations and interactions [75, 89-93] and learning abilities need social interactions to be effective [91]. Hence, the implementation of participatory learning activities could be an important strategy in the battle against CD. Events using audio-visual tools may be implemented at healthcare facilities. For example, popular theatre could be used as a tool for communication and dissemination of health information [94-96]. Plays can overcome literacy barriers. Further, workshops and seminars could be organized with community members, health center personnel and schoolteachers, as they are important intermediaries. Indeed, education of elementary school children has been found to be an effective strategy to promote behavior change in parents $[97,98]$. It is of great significance that communities are actively involved in the identification of problems and needs, search for solutions and evaluation of applied measures. Successful experiences involving community participation in CD control have been reported across Latin America [42, 99-105]. Bottom-up approaches could be applied [106] putting emphasis on preventive or personal protection measures and environmental management. Long-term community-based surveillance strategies need to be applied along with governmentsponsored insecticide spraying. For example, community members could be engaged in voluntary and active entomological surveillance as they were very efficient in capturing triatomine bugs during the fieldwork. Triatoma vectors could be searched, deposited in special containers and reported to community leaders or coordinators. Ideally, fumigation of infested houses should follow, which could also be accomplished by community members who received special training in insecticide spraying. Previous studies reported experiences with people who sprayed their own houses $[102,105]$. The use of mosquito nets, window insect screens, cleaning activities, personal hygiene, mud coating of walls, and insect traps are feasible preventive measures that could be imposed by the community. The use of physical barriers (insect screens) was identified as a good alternative strategy for the control of sylvatic and peridomiciliated vectors [107-109]. Another alternative might be the use of insecticideimpregnated materials, which has been proved to be a cost-effective option [110,111]. Also low-cost improvements using local materials have been reported as a successful intervention [112, 113].

\section{Conclusions}

This study reveals a significant discrepancy between local knowledge of $\mathrm{CD}$ and the practices to reduce risk of transmission among the studied ethnic groups Ayoreo, Guaraní and Quechua. In parts, this can be explained by an insufficient understanding of vector disease transmission, but also the lack of an acute effect on health upon infection may account for the apparent indifference towards vector bites. Indigenous ethnomedical knowledge systems differ from Western concepts of chronic diseases. This was particularly evident among the Ayoreo, who also suffered from a range of other diseases, including, acute respiratory infections, acute diarrheal diseases, diabetes and AIDS [55]. Clearly, the indigenous communities in this study did not associate danger with $\mathrm{CD}$ as it may not be lethal among the majority of the infected people [33, 43]. Although past insecticide spraying campaigns in the Isoso region temporarily reduced the vector infestation in the villages, during this fieldwork people literally cohabited with T. infestans. The bugs collected in domestic dwellings among the Guaraní showed an approximately $70 \%$ overall infection, clearly indicating hyperendemic disease transmission among indigenous communities in this area. Intriguingly, no action was taken to eliminate the bugs from the dwellings. Public health programmes aim to replace "false" beliefs with "accurate" knowledge. By changing community 
knowledge, it is assumed, behavior will also be changed [44]. Although education programmes have raised awareness, they did not greatly affect the behavior of people. Accordingly, a significantly high proportion of the affected indigenous informants had some knowledge of the disease vector but they did not translate it to prevention or protection practices. Therefore, a change of perception regarding triatomine bugs as being potentially lethal is indispensable. While it is unnecessary that the affected population understands $\mathrm{CD}$ from a biomedical perspective, the scientific information needs to be translated into culturally appropriate categories that are sensitive to indigenous values, traditions and motivations [79]. An early and thorough education of children on the danger of triatomine bugs should accompany the current anti-CD campaigns. Continued vector control activities (e.g. regular collecting of bugs from dwellings) with community-based health intervention programmes using strategies of community participation could be an important strategy to break the vicious circle between hyperendemic $C D$ communities and hyperinfected vectors infesting their houses. Two decades after disease intervention, the rural populations still suffer from T. cruzi infections, which could be reduced solely by changing the widespread view on the nature of threat by vector bites. Overall, we believe that through the involvement and experience of local people the impact of current interventions should be translated into changes of practice.

\section{Abbreviations}

AIDS: Acquired Immune Deficiency Syndrome; BID: Banco Interamericano de Desarrollo; CD: Chagas disease; PAHO: Pan American Health Organization; PCR: polymerase chain reaction; WHO: World Health Organization.

\section{Acknowledgments}

We would like to acknowledge the local informants in the different indigenous communities, in particular the informants Dope Etacorei, Rocio Picanere and Donato Abaguazu. We thank Giovanna Rocio Almanza Vega, Universidad Mayor de San Andres, Bolivia, for logistical assistance during fieldwork.

\section{Authors' contributions}

AS performed fieldwork, collected and analyzed data, performed real-time PCR and wrote the paper. JG performed and supervised fieldwork in the Chaco, collected data and revised the paper. Both authors read and approved the final manuscript.

\section{Funding}

Research was funded by the PhD fellowship (Early Stage Researcher) under the EU FP7 Marie Curie Initial Training Network (ITN) MedPlant (MedPlant. Project ID: 606895).

\section{Availability of data and materials}

Data supporting the results reported in the article, if not provided in the article, can be obtained from authors. The datasets used and/or analyzed during the current study are available from the corresponding author upon reasonable request.

\section{Ethics approval and consent to participate}

Prior informed consent and permission to work in the study communities were solicited during in-person meetings with community leaders, where a clear explanation about the objectives of the study was given. The participation was voluntary, as oral consent was obtained in each interview. An overall overview of the study was provided to individual informants. After the interviews, we provided general basic information (education) about CD transmission and prevention measures.

\section{Consent for publication}

Consent to publish (Fig. 5c) was obtained from that person.

\section{Competing interests}

The authors declare that they have no competing interests.

Received: 15 February 2019 Accepted: 30 May 2019

Published online: 10 June 2019

References

1. Rassi A, Rassi A, Marin-Neto JA. Chagas disease. Lancet. 2010:375:1388-402

2. World Health Organization. WHO |Chagas disease (American trypanosomiasis); 2018. http://www.who.int/news-room/fact-sheets/detail/chaga s-disease-(american-trypanosomiasis). Accessed 28 May 2019.

3. Noireau F, Diosque P, Jansen AM. Trypanosoma cruzi: adaptation to its vectors and its hosts. Vet Res. 2009;40:26.

4. Coura JR, Borges-Pereira J. Chagas disease: 100 years after its discovery. A systemic review. Acta Trop. 2010;115:5-13.

5. Gaspe MS, Provecho YM, Cardinal MV, del Pilar Fernández M, Gürtler RE. Ecological and sociodemographic determinants of house infestation by Triatoma infestans in indigenous communities of the Argentine Chaco. PLoS Negl Trop Dis. 2015;9:e0003614.

6. Hotez PJ, Molyneux DH, Fenwick A, Kumaresan J, Sachs SE, Sachs JD, et al. Control of neglected tropical diseases. N Engl J Med. 2007;357:1018-27.

7. Lee BY, Bacon KM, Bottazzi ME, Hotez PJ. Global economic burden of Chagas disease: a computational simulation model. Lancet Infect Dis. 2013;13:342-8

8. de Araújo-Jorge TC, Medrano-Mercado N. Chagas disease in Bolivia: a brief review of the urban phenomena. Rev Biomédica. 2009;20:236-44.

9. Cassab JRA, Noireau F, Guillén G. La enfermedad de Chagas en Bolivia Conocimientos científicos al inicio del Programa de Control (19982002). La Paz, Bolivia: Ministerio de Salud y Previsión Social; 1999.

10. Organización Panamericana de la Salud. Estimación cuantitativa de la enfermedad de Chagas en las Americas. Uruguay: Montevideo; 2006.

11. World Health Organization. Chagas disease in Latin America: an epidemiological update based on 2010 estimates. Wkly Epidemiol Rec. 2015;6:33-44

12. Ehrenberg JP, Ault SK. Neglected diseases of neglected populations: thinking to reshape the determinants of health in Latin America and the Caribbean. BMC Public Health. 2005;5:119.

13. Gurevitz JM, Ceballos LA, Gaspe MS, Alvarado-Otegui JA, Enríquez GF, Kitron $U$, et al. Factors affecting infestation by Triatoma infestans in a rural area of the humid Chaco in Argentina: a multi-model inference approach. PLoS Negl Trop Dis. 2011;5:e1349.

14. Hidron Al, Gilman RH, Justiniano J, Blackstock AJ, LaFuente C, Selum W, et al. Chagas cardiomyopathy in the context of the chronic disease transition. PLoS Negl Trop Dis. 2010;4:e688.

15. Samuels AM, Clark EH, Galdos-Cardenas G, Wiegand RE, Ferrufino L, Menacho S, et al. Epidemiology of and impact of insecticide spraying on Chagas disease in communities in the Bolivian Chaco. PLoS Negl Trop Dis. 2013;7:e2358.

16. Cardinal MV, Orozco MM, Enriquez GF, Ceballos LA, Gaspe MS, AlvaradoOtegui JA, et al. Heterogeneities in the ecoepidemiology of Trypanosoma cruzi infection in rural communities of the Argentinean Chaco. Am J Trop Med Hyg. 2014;90:1063-73.

17. Lucero RH, Brusés BL, Cura Cl, Formichelli LB, Juiz N, Fernández GJ, et al. Chagas' disease in Aboriginal and Creole communities from the Gran Chaco Region of Argentina: seroprevalence and molecular parasitological characterization. Infect Genet Evol. 2016;41:84-92.

18. Moretti E, Castro I, Franceschi C, Basso B. Chagas disease: serological and electrocardiographic studies in Wichi and Creole communities 
of Misión Nueva Pompeya, Chaco. Mem Inst Oswaldo Cruz. 2010;105:621-6.

19. Castro JA, DeMecca MM, Bartel LC. Toxic side effects of drugs used to treat Chagas' disease (American Trypanosomiasis). Hum Exp Toxicol. 2006:25:471-9.

20. Coura JR, de Castro SL. A critical review on Chagas disease chemotherapy. Mem Inst Oswaldo Cruz. 2002;97:3-24.

21. Dias JCP. Southern Cone Initiative for the elimination of domestic populations of Triatoma infestans and the interruption of transfusional Chagas disease. Historical aspects, present situation, and perspectives. Mem Inst Oswaldo Cruz. 2007;102(Suppl. 1):11-8.

22. Schofield CJ, Kabayo JP. Trypanosomiasis vector control in Africa and Latin America. Parasite Vectors. 2008;1:24.

23. Fiusa LJ, Zuniga C, Vera M, Salvatella R, Fidel SM, Enriquez M. Situacional de la epidemiología y el control de la enfermedad de Chagas en Bolivia. Gac Médica Boliv. 2011;34:57.

24. Inter-American Development Bank. Bolivian Epidemiological Shield and Support for Health-Sector Reform (BO - 0115); 1999. http://www.iadb. org/projectDocument.cfm?id=435533. Accessed 8 Apr 2013.

25. Ley 3374. La Paz: Estado Plurinacional de Bolivia; 2006.

26. Holveck JC, Ehrenberg JP, Ault SK, Rojas R, Vasquez J, Cerqueira MT, et al. Prevention, control, and elimination of neglected diseases in the Americas: pathways to integrated, inter-programmatic, inter-sectoral action for health and development. BMC Public Health. 2007;7:6.

27. Ávila Montes G, Martínez Hernández M, Ponce C, Ponce E, Soto Hernández R. La enfermedad de Chagas en la zona central de Honduras: conocimientos, creencias y prácticas. Pan Am J Public Health. 1998;3:158-63.

28. Cabrera R, Mayo C, Suárez N, Infante C, Náquira C, García-Zapata M. Knowledge, attitudes, and practices concerning Chagas disease in schoolchildren from an endemic area in Peru. Cad Saúde Pública. 2003:19:147-54.

29. Valdez-Tah A, Huicochea-Gómez L, Ortega-Canto J, Nazar-Beutelspacher A, Ramsey JM. Social representations and practices towards triatomines and Chagas disease in Calakmul, México. PLoS ONE. 2015;10:e0132830.

30. Villela MM, Pimenta DN, Lamounier PA, Dias JCP. Avaliação de conhecimentos e práticas que adultos e crianças têm acerca da doença de Chagas e seus vetores em região endêmica de Minas Gerais, Brasil. Cad Saude Publica. 2009;25:1701-10

31. Williams-blangero S, VandeBerg JL, Teixeira ARL. Attitudes towards Chagas' disease in an endemic Brazilian community. Cad Saúde Pública, Rio Janeiro. 1999:15:7-13.

32. Yevstigneyeva V, Camara-Mejia J, Dumonteil E. Analysis of children's perception of triatomine vectors of Chagas disease through drawings: opportunities for targeted health education. PLoS Negl Trop Dis. 2014:8:e3217.

33. Dell'Arciprete A, Braunstein J, Touris C, Dinardi G, Llovet I, Sosa-Estani S. Cultural barriers to effective communication between Indigenous communities and health care providers in Northern Argentina: an anthropological contribution to Chagas disease prevention and control. Int $J$ Equity Health. 2014;13:6.

34. Genero S, Nasir J, Cayre A, Pascual M, Gorostegui F, Chaparro R, et al. Knowledge and attitudes about Chagas disease in the population of Avia Terai, Province of Chaco. Rev Argent Salud Pública. 2011;2:6-10.

35. Hurtado LA, Calzada JE, Pineda V, González K, Santamaría AM, Cáceres L, et al. Conocimientos y factores de riesgo relacionados con la enfermedad de Chagas en dos comunidades panameñas donde Rhodnius pallescens es el vector principal. Biomédica. 2014;34:260-70.

36. López SM, Salomón OD. Conocimiento, percepción y actitud sobre la enfermedad de Chagas en un centro de referencia urbano. Rev Patol Trop. 2015;44:409-22.

37. Rosecrans K, Cruz-Martin G, King A, Dumonteil E. Opportunities for improved Chagas disease vector control based on knowledge, attitudes and practices of communities in the Yucatan Peninsula, Mexico. PLoS Negl Trop Dis. 2014;8:e2763.

38. Sanabria Rojas HA, Guevara Saravia M, Bianchi Vallejos S, Vera Ortiz G, Palomino Salcedo G. Estudio sobre el vector de la enfermedad de Chagas. Estudio cualitativo en Parcona. Universidades. 2002;24. http:// www.redalyc.org/exportarcita.oa?id=37302404. Accessed 28 May 2019.
39. Sanmartino M. “Tener Chagas” en contexto urbano: concepciones de varones residentes en la región de la Plata (Argentina). Rev Biomed. 2009:20:216-27.

40. Sanmartino M, Crocco L. Conocimientos sobre la enfermedad de Chagas y factores de riesgo en comunidades epidemiológicamente diferentes de Argentina. Rev Panam Salud Pública. 2000;7:173-8.

41. Caballero Zamora A, De Muynck A. Actitudes y creencias de los indios quechuas de la provincia de Zudáñez, departamento de Chuquisaca, Bolivia, frente al vector de la enfermedad del Chagas. In: Cassab J, Noireau F, Guillen G, editors. La enfermedad de Chagas en Bolivia. Conocimientos científicos al inicio del Programa Control (1998-2002). La Paz: Ministerio de Salud y Previsión Social; 1999. p. 86-90.

42. Lardeux F, Depickère S, Aliaga C, Chavez T, Zambrana L. Experimental control of Triatoma infestans in poor rural villages of Bolivia through community participation. Trans R Soc Trop Med Hyg. 2015;109:150-8.

43. Verdú J, Ruiz MT. Control del Chagas en comunidades guaraníes: conocimiento y hábitos higiénicos dentro del Proyecto de Mejoramiento de Viviendas en Bolivia. Gac Sanit. 2003;17:166-8.

44. Manderson L. Applying medical anthropology in the control of infectious disease. Trop Med Int Health. 1998:3:1020-7.

45. Ventura-Garcia L, Roura M, Pell C, Posada E, Gascón J, Aldasoro E, et al. Socio-Cultural Aspects of Chagas disease: a systematic review of qualitative research. PLoS Negl Trop Dis. 2013;7:e2410.

46. Barrett MP, Burchmore RJ, Stich A, Lazzari JO, Frasch AC, Cazzulo JJ, et al. The trypanosomiases. Lancet. 2003;362:1469-80.

47. Ribeiro AL, Nunes MP, Teixeira MM, Rocha MOC. Diagnosis and management of Chagas disease and cardiomyopathy. Nat Rev Cardiol. 2012;9:576-89.

48. Brenière SF, Bosseno MF, Noireau F, Yacsik N, Liegeard P, Aznar C, et al. Integrate study of a Bolivian population infected by Trypanosoma cruzi, the Agent of Chagas Disease. Mem Inst Oswaldo Cruz. 2002:97:289-95.

49. Chippaux J-P, Postigo JR, Santalla JA, Schneider D, Brutus L. Epidemiological evaluation of Chagas disease in a rural area of southern Bolivia. Trans R Soc Trop Med Hyg. 2008;102:578-84.

50. Gürtler RE. Sustainability of vector control strategies in the Gran Chaco Region: current challenges and possible approaches. Mem Inst Oswaldo Cruz. 2009;104:52-9.

51. Ministerio de Salud. Revista Epidemiologica. La Paz, Bolivia; 2015. https ://www.minsalud.gob.bo/images/Libros/epidemio/Revista-Epidemiolo gica_opt.pdf. Accessed 28 May 2019.

52. Desarrollo Económico Local en la Provincia Chiquitos. 1st edition. Santa Cruz de la Sierra: CEAM-CEPAD; 2007. http://www.dhl.hegoa.ehu.es/ ficheros/0000/0443/Desarrollo_Econ\%C3\%B3mico_Local_en_Chiqu itos.pdf.

53. Estrategia de Desarrollo Económico Local. Municipio de San José. 2006. https://provinciachiquitos.files.wordpress.com/2006/09/estrategia-dedesarrollo-municipio-de-san-jose-de-chiquitos.pdf.

54. Fabre A. Los pueblos del Gran Chaco y sus lenguas, cuarta parte: Los zamuco. Suplemento Antropológico. 2007:42:271-323.

55. Roca Ortiz I, Cutamiño Dosapé T, Picaneré Chiqueno R, Nostas Ardaya M, Sanabria Salmón CE, Nominé Chiqueno T. Pigasipiedie ijí yoquijoningai. Aproximaciones a la situación del derecho a la salud del pueblo Ayoreode en Bolivia. Santa Cruz de la Sierra, Bolivia: APCOB, CANOB; 2012

56. Brenière SF, Aliaga C, Waleckx E, Buitrago R, Salas R, Barnabé C, et al. Genetic characterization of Trypanosoma cruzi DTUs in wild Triatoma infestans from Bolivia: predominance of TCI. PLoS Negl Trop Dis. 2012;6:e1650

57. Brenière SF, Buitrago R, Waleckx E, Depickère S, Sosa V, Barnabé C, et al. Wild populations of Triatoma infestans: compilation of positive sites and comparison of their ecological niche with domestic population niche. Acta Trop. 2017;176:228-35

58. Cortez MR, Emperaire L, Piccinali R, Gürtler RE, Torrico F, Jansen AM, et al. Sylvatic Triatoma infestans (Reduviidae, Triatominae) in the Andean valleys of Bolivia. Acta Trop. 2007;102:47-54.

59. Cardinal MV, Sartor PA, Gaspe MS, Enriquez GF, Colaianni I, Gürtler RE. High levels of human infection with Trypanosoma cruzi associated with the domestic density of infected vectors and hosts in a rural area of northeastern Argentina. Parasit Vectors. 2018;11:492. 
60. Fernandez AB, Nunes MCP, Clark EH, Samuels A, Menacho S, Gomez $J$, et al. Electrocardiographic and echocardiographic abnormalities in Chagas disease findings in residents of rural Bolivian communities hyperendemic for Chagas disease. Glob Heart. 2015;10:159-66.

61. Noireau F, Gutierrez T, Flores R, Brenière F, Bosseno MF, Wisnivesky-Coll C. Ecogenetics of Triatoma sordida and Triatoma guasayana (Hemiptera : Reduviidae) in the Bolivian Chaco. Mem Inst Oswaldo Cruz. 1999;94:451-7.

62. Perez E, Monje M, Chang B, Buitrago R, Parrado R, Barnabé C, et al. Predominance of hybrid discrete typing units of Trypanosoma cruzi in domestic Triatoma infestans from the Bolivian Gran Chaco region. Infect Genet Evol. 2013;13:116-23.

63. Acosta N, López E, Lewis MD, Llewellyn MS, Gómez A, Román F, et al. Hosts and vectors of Trypanosoma cruzi discrete typing units in the Chagas disease endemic region of the Paraguayan Chaco. Parasitology. 2017;144:884-98

64. Noireau F, Flores R, Gutierrez T, Dujardin JP. Detection of sylvatic dark morphs of Triatoma infestans in the Bolivian Chaco. Mem Inst Oswaldo Cruz. 1997;92:583-4.

65. Waleckx E, Depickère S, Salas R, Aliaga C, Monje M, Calle H, et al. New discoveries of sylvatic Triatoma infestans (Hemiptera: Reduviidae) throughout the Bolivian Chaco. Am J Trop Med Hyg. 2012;86:455-8.

66. Briceño-León R, Méndez Galván J. The social determinants of Chagas disease and the transformations of Latin America. Mem Inst Oswaldo Cruz. 2007;102:109-12.

67. Provecho YM, Gaspe MS, del Pilar Fernández M, Enriquez GF, Weinberg D, Gürtler RE. The peri-urban interface and house infestation with Triatoma infestans in the Argentine Chaco: an underreported process? Mem Inst Oswaldo Cruz. 2014;109:923-34.

68. Salas Clavijo NA, Postigo JR, Schneider D, Santalla JA, Brutus L, Chippaux JP. Prevalence of Chagas disease in pregnant women and incidence of congenital transmission in Santa Cruz de la Sierra, Bolivia. Acta Trop. 2012;124:87-91.

69. Laura Sandoval D, Zurita Añez H. Riesgo de transmisión de Trypanosoma cruzi por medio de triatominos infectados en la localidad de Paurito, Municipio de Cotoca - Santa Cruz, 2009. Univ Cienc Soc. 2012;6:14-20

70. Loza-Murguía M, Noireau F. Vectorial capacity of Triatoma guasayana (Wygodzinsky \& Abalos) (Hemiptera: Reduviidae) compared with two other species of epidemic importance. Neotrop Entomol. 2010;39:799-809.

71. Bourdy G, Chavez De Michel LR, Roca-Coulthard A. Pharmacopoeia in a shamanistic society: the Izoceño-Guaraní (Bolivian Chaco). J Ethnopharmacol. 2004;91:189-208.

72. Vandebroek I, Thomas E, Sanca S, Van Damme P, Van Van L, De Kimpe N. Comparison of health conditions treated with traditional and biomedical health care in a Quechua community in rural Bolivia. J Ethnobiol Ethnomed. 2008:4:1.

73. Cummings KL, Tarleton RL. Rapid quantitation of Trypanosoma cruzi in host tissue by real-time PCR. Mol Biochem Parasitol. 2003;129:53-9.

74. Lozada M, Ladio ANA, Weigandt M. Cultural transmission of ethnobotanical knowledge in a rural community of northwestern Patagonia, Argentina. Econ Bot. 2006:60:374-85.

75. Zarger RK, Stepp JR. Persistence of botanical knowledge among Tzeltal Maya children. Curr Anthropol. 2004:45:413-8.

76. Lind U. Die Medizin der Ayore-Indianer im Gran Chaco. Beiträge zur Ethnomedizin, Ethnobotanik und Ethnozoologie V. München: Kommission Klaus Renner Verlag; 1974.

77. Bessire L. Ujnarone Chosite: ritual poesis, curing chants and becoming Ayoreo in the Gran Chaco. J Soc Am. 2011;97:259-89.

78. Forsyth C. Controlled but not cured: structural processes and explanatory models of Chagas disease in tropical Bolivia. Soc Sci Med. 2015;145:7-16.

79. Bastien J. The kiss of death: Chagas' disease in the Americas. Salt Lake City: The University of Utah Press; 1998.

80. Arrom C, Arrom M, Arrom C, Rolón M, Vega M, Rojas de Arias A. Comportamientos que favorecen la dinámica de reinfestación de Triatoma infestans del Chaco paraguayo. Mem Inst Investig Cienc Salud. 2013;11:7-15

81. Cecere MC, Gürtler RE, Chuit R, Cohen JE. Effects of chickens on the prevalence of infestation and population density of Triatoma infestans in rural houses of north-west Argentina. Med Vet Entomol. 1997;11:383-8.

82. Fabrizio MC, Schweigmann NJ, Bartoloni NJ. Modelling American trypanosomiasis in an endemic zone: application to the initial spread of household infection in the Argentine Chaco. Zoonoses Public Health. 2014;61:545-59.

83. Nouvellet P, Dumonteil E, Gourbière S. The improbable transmission of Trypanosoma cruzi to human: the missing link in the dynamics and control of Chagas disease. PLoS Negl Trop Dis. 2013;7:e2505.

84. Ganley BJ, Rosario DI. The smoking attitudes, knowledge, intent, and behaviors of adolescents and young adults: implications for nursing practice. J Nurs Educ Pract. 2013;3:40-50.

85. Cerón A, Ruano AL, Sánchez S, Chew AS, Díaz D, Hernández A, et al. Abuse and discrimination towards indigenous people in public health care facilities: experiences from rural Guatemala. Int J Equity Health. 2016;15:77.

86. Gamlin JB. Shame as a barrier to health seeking among indigenous Huichol migrant labourers: an interpretive approach of the "violence continuum" and "authoritative knowledge". Soc Sci Med. 2013;97:75-81.

87. Espinoza N, Borrás R, Abad-Franch F. Chagas disease vector control in a hyperendemic setting: the first 11 years of intervention in Cochabamba, Bolivia. PLoS Negl Trop Dis. 2014;8:e2782.

88. Peralta C. Estudio de la mortalidad por Chagas. El caso de Argentina; 1999. https://www.academia.edu/20020067/Estudio_de_la_morta lidad_por_Chagas._El_caso_de_Argentina._Año_1999. Accessed 28 May 2019.

89. Zarger RK. Children's ethnoecological knowledge: situated learning and the cultural transmission of subsistence knowledge and skills among Q'eqchi' Maya. Ph.D. Thesis, University of Georgia, USA; 2002.

90. Hunn ES. Evidence for the precocious acquisition of plant knowledge by Zapotec children. In: Stepp JR, Wyndham FS, Zarger RK, editors. Ethnobiology and biocultural diversity. Athens: International Society of Ethnobiology; 2002. p. 604-13.

91. Atran S, Sperber D. Learning without teaching: its place in culture. In: Landsmann LT, editor. Culture schooling and psychological development. Norwood, NJ: Ablex; 1991. p. 39-55. http://www.sscne t.ucla.edu/comm/steen/cogweb/Abstracts/Sperber_Atran_91.html. Accessed 28 May 2019.

92. Reyes-García V, Broesch J, Calvet-Mir L, Fuentes-Peláez N, Mcdade TW Parsa S, et al. Cultural transmission of ethnobotanical knowledge and skills: an empirical analysis from an Amerindian society. Evol Hum Behav. 2009;30:274-85

93. Eyssartier C, Ladio AH, Lozada M. Cultural transmission of traditional knowledge in two populations of north-western Patagonia. J Ethnobiol Ethnomed. 2008:4:25.

94. Ghosh SK, Patil RR, Tiwari S, Dash AP. A community-based health education programme for bio-environmental control of malaria through folk theatre (Kalajatha) in rural India. Malar J. 2006:5:123.

95. Kidd R. Popular theatre and nonformal education in the Third World: five strands of experience. Int Rev Educ. 1985;30:265-87.

96. Mbizvo E. Essay: theatre-a force for health promotion. Lancet. 2006:368(Suppl. 1):30-1.

97. Das JK, Salam RA, Arshad A, Maredia H, Bhutta ZA. Community based interventions for the prevention and control of non-helmintic NTD. Infect Dis Poverty. 2014;3:24.

98. Winch PJ, Leontsini E, Rigau-Pérez J, Clark GG, Gubler DJ. Communitybased dengue prevention programs in Puerto Rico: impact on knowledge, behavior, and residential mosquito infestation. Am J Trop Med Hyg. 2002;67:363-70.

99. Abad-Franch F, Vega MC, Rolón MS, Santos WS, de Arias AR. Community participation in Chagas disease vector surveillance: systematic review. PLoS Negl Trop Dis. 2011;5:e1207.

100. Cardinal MV, Lauricella MA, Marcet PL, Orozco MM, Kitron U, Gürtler RE. Impact of community-based vector control on house infestation and Trypanosoma cruzi infection in Triatoma infestans, dogs and cats in the Argentine Chaco. Acta Trop. 2007;103:201-11.

101. De Urioste-Stone SM, Pennington PM, Pellecer E, Aguilar TM, Samayoa G, Perdomo HD, et al. Development of a community-based intervention for the control of Chagas disease based on peridomestic 
animal management: an eco-bio-social perspective. Trans R Soc Trop Med Hyg. 2014;109:159-67.

102. García-Zapata MT, Marsden PD. Chagas' disease: control and surveillance through use of insecticides and community participation in Mambaí, Goiás, Brazil. Bull Pan Am Health Organ. 1993;27:265-79.

103. Gürtler R, Kitron U, Cecere M, Segura E, Cohen J. Sustainable vector control and management of Chagas disease in the Gran Chaco, Argentina. Proc Natl Acad Sci USA. 2007;104:16194-9.

104. Gürtler RE, Yadon ZE. Eco-bio-social research on community-based approaches for Chagas disease vector control in Latin America. Trans $R$ Soc Trop Med Hyg. 2014;109:91-8.

105. Vazquez-Prokopec GM, Spillmann C, Zaidenberg M, Kitron U, Gürtler RE. Cost-effectiveness of Chagas disease vector control strategies in northwestern Argentina. PLoS Negl Trop Dis. 2009;3:e363.

106. Cornwall A, Jewkes R. What is participatory research? Soc Sci Med. 1995:41:1667-76

107. Barbu C, Dumonteil E, Gourbière S. Optimization of control strategies for non-domiciliated Triatoma dimidiata, Chagas disease vector in the Yucatán Peninsula, Mexico. PLoS Negl Trop Dis. 2009;3:e416.

108. Ferral J, Chavez-Nuñez L, Euan-Garcia M, Ramirez-Sierra MJ, NajeraVazquez MR, Dumonteil E. Comparative field trial of alternative vector control strategies for non-domiciliated Triatoma dimidiata. Am J Trop Med Hyg. 2010;82:60-6.
109. Waleckx E, Cámara-Mejía J, Ramírez-Sierra MJ, Cruz-Chan V, RosadoVallado M, Vázquez-Narváez S, et al. Una intervención innovadora de ecosalud para el control vectorial de la enfermedad de Chagas en Yucatán, México. Rev Biomédica. 2015;26:75-86.

110. Kroeger A, Ordoñez-Gonzalez J, Behrend M, Alvarez G. Bednet impregnation for Chagas disease control: a new perspective. Trop Med Int Health. 1999:4:194-8.

111. Kroeger A, Villegas E, Ordoñez-González J, Pabon E, Scorza JV. Prevention of the transmission of Chagas' disease with pyrethroid-impregnated materials. Am J Trop Med Hyg. 2003;68:307-11.

112. Lucero DE, Morrissey LA, Rizzo DM, Rodas A, Garnica R, Stevens L, et al. Ecohealth interventions limit triatomine reinfestation following insecticide spraying in La Brea, Guatemala. Am J Trop Med Hyg. 2013:88:630-7.

113. Schofield CJ, Marsden PD. The effect of wall plaster on a domestic population of Triatoma infestans. BullPan Am Heal Organ. 1982;16:356-60.

\section{Publisher's Note}

Springer Nature remains neutral with regard to jurisdictional claims in published maps and institutional affiliations.
Ready to submit your research? Choose BMC and benefit from:

- fast, convenient online submission

- thorough peer review by experienced researchers in your field

- rapid publication on acceptance

- support for research data, including large and complex data types

- gold Open Access which fosters wider collaboration and increased citations

- maximum visibility for your research: over $100 \mathrm{M}$ website views per year

At BMC, research is always in progress.

Learn more biomedcentral.com/submissions 